\title{
DEGASSING HISTORY OF WATER, SULFUR, AND CARBON IN SUBMARINE LAVAS FROM KILAUEA VOLCANO, HAWAII
}

\author{
JACQUELINE EABY DIXON, DAVID A. CLAGUE ${ }^{2}$, AND EDWARD M. STOLPER
}

Division of Geological and Planetary Sciences, California Institute of Technology, Pasadena, CA 91125

\section{ABSTRACT}

Major, minor, and dissolved volatile element concentrations were measured in tholeiitic glasses from the submarine portion (Puna Ridge) of the east rift zone of Kilauea Volcano, Hawaii. Dissolved $\mathrm{H}_{2} \mathrm{O}$ and $\mathrm{S}$ concentrations display a wide range relative to nonvolatile incompatible elements at all depths. This range cannot be readily explained by fractional crystallization, degassing of $\mathrm{H}_{2} \mathrm{O}$ and $\mathrm{S}$ during eruption on the seafloor, or source region heterogeneities. Dissolved $\mathrm{CO}_{2}$ concentrations, in contrast, show a positive correlation with eruption depth and typically agree within error with the solubility at that depth. We propose that most magmas along the Puna Ridge result from (1) mixing of a relatively volatile-rich, undegassed component with magmas that experienced low pressure (perhaps subaerial) degassing during which substantial $\mathrm{H}_{2} \mathrm{O}, \mathrm{S}$, and $\mathrm{CO}_{2}$ were lost, followed by (2) fractional crystallization of olivine, clinopyroxene, and plagioclase from this mixture to generate a residual liquid; and (3) further degassing, principally of $\mathrm{CO}_{2}$ for samples erupted deeper than $1000 \mathrm{~m}$, during eruption on the seafloor. The degassed end member may form at upper levels of the summit magma chamber (assuming less than lithostatic pressure gradients), during residence at shallow levels in the crust, or during sustained summit eruptions. The final phase of degassing during eruption on the seafloor occurs slowly enough to achieve melt/vapor equilibrium during exsolution of the typically $\mathrm{CO}_{2}$-rich vapor phase. We predict that average Kilauean primary magmas with $16 \% \mathrm{MgO}$ contain $\sim 0.47 \mathrm{wt} \% \mathrm{H}_{2} \mathrm{O}, \sim 900 \mathrm{ppm} \mathrm{S}$, and have $\delta \mathrm{D}$ values of $\sim-30$ to $-40 \%$. Our model predicts that submarine lavas from wholly submarine volcanoes (i.e., Loihi), for which there is no opportunity to generate the degassed end member by low pressure degassing, will be enriched in volatiles relative to those from volcanoes whose summits have breached the sea surface (i.e., Kilauea and Mauna Loa).

\section{INTRODUCTION}

Water and sulfur are much more soluble in basaltic liquids than carbon dioxide. These solubility differences, combined with volcanic gas emission data, have been used to develop two-stage models of the outgassing of Kilauea magmas (e.g., Gerlach and Graeber 1985; Greenland et al. 1985; Gerlach 1986). The first stage occurs in the summit magma chamber where most of the $\mathrm{CO}_{2}$ and lesser amounts of $\mathrm{SO}_{2}$ and $\mathrm{H}_{2} \mathrm{O}$ degas. The second stage occurs during subaerial eruptions where most of the remaining $\mathrm{CO}_{2}, \mathrm{SO}_{2}$, and $\mathrm{H}_{2} \mathrm{O}$ degasses. A second stage of degassing of $\mathrm{H}_{2} \mathrm{O}$ and $\mathrm{S}$ is not expected to occur in magmas erupted along Kilauea's submarine rift zones deeper than about $1000 \mathrm{~m}$ because the pressure at the depth of eruption is sufficient to prevent exsolution of significant $\mathrm{H}_{2} \mathrm{O}$ and $\mathrm{S}$. Consequently, these submarine magmas

\footnotetext{
${ }^{1}$ Manuscript received February 2, 1990; accepted January 8, 1991.

${ }^{2}$ U.S. Geological Survey, 345 Middlefield Road, Menlo Park, CA 94025.

[Journal of Geology, 1991, vol. 99, p. 371-394] (C) 1991 by The University of Chicago. All rights reserved.
}

$0022-1376 / 91 / 9903-0012 \$ 1.00$ have been thought to contain concentrations of $\mathrm{H}_{2} \mathrm{O}$ and $\mathrm{S}$ that have been largely unchanged on eruption. Previous studies of $\mathrm{H}_{2} \mathrm{O}$ and $\mathrm{S}$ in Hawaiian submarine basaltic glasses (e.g., Moore and Fabbi 1971; Killingley and Muenow 1975; Muenow et al. 1979; Harris and Anderson 1983; Kyser and O'Neil 1984; Byers et al. 1985; Garcia et al. 1989) have focused on constraining their concentrations and using these data to make inferences about their concentrations in primitive magmas and heterogeneities in mantle source regions. We will show, however, based on new measurements of major and minor element and dissolved $\mathrm{H}_{2} \mathrm{O}, \mathrm{CO}_{2}$, and $\mathrm{S}$ concentrations in a suite of tholeiitic glasses from the submarine portion of the east rift zone of Kilauea Volcano, Hawaii (hereafter referred to as the Puna Ridge), that even many submarine magmas from Kilauea have lost water and sulfur during complex degassing histories and that inferences regarding volatile concentrations in primitive Hawaiian magmas and mantle source regions may require revision.

\section{GEOLOGIC SETTING}

The Puna Ridge is the submarine portion of the $130 \mathrm{~km}$ long east rift zone of Kilauea Volcano. It extends $75 \mathrm{~km}$ from the shoreline 


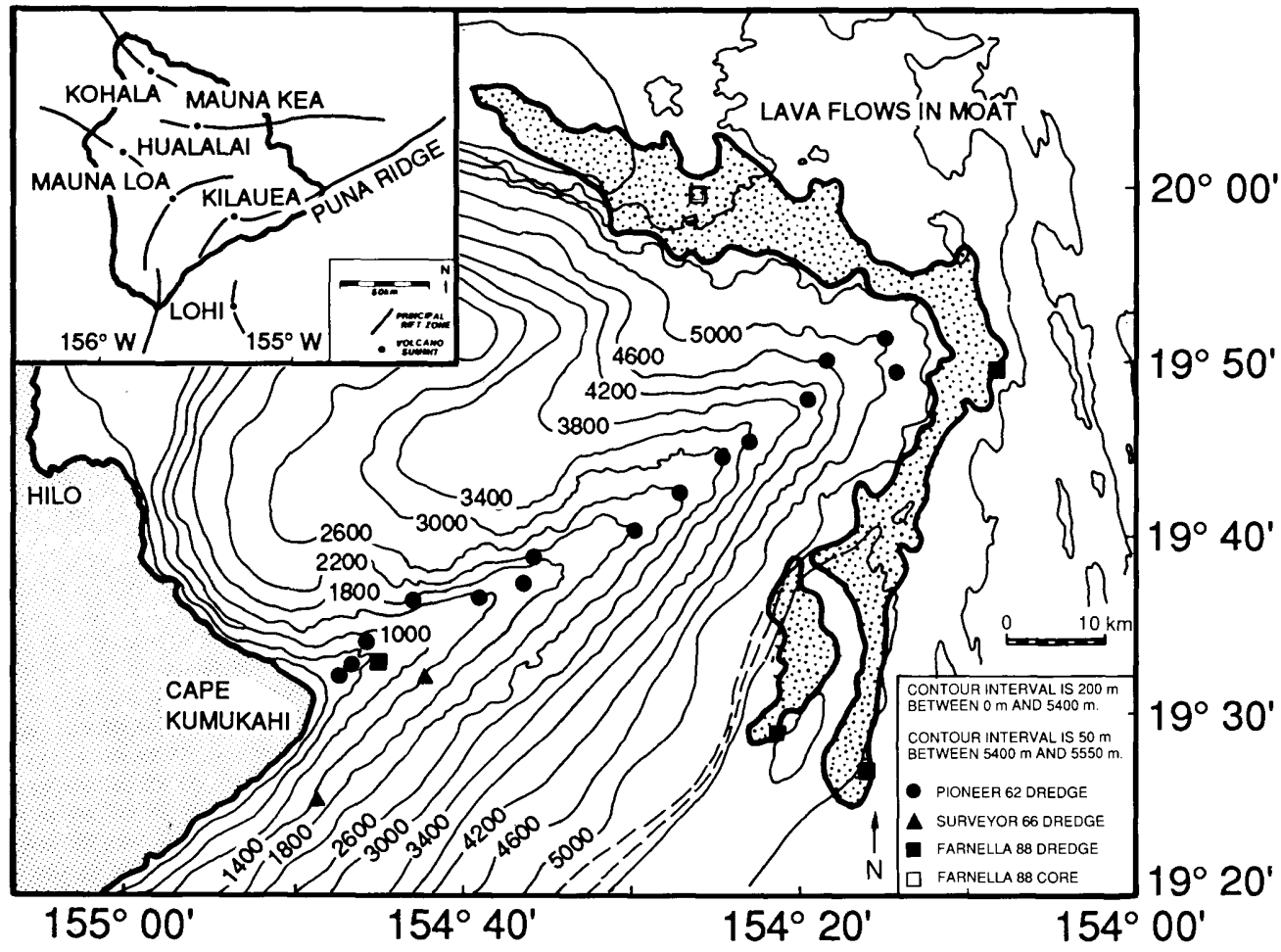

FIG. 1.-Dredge locations of samples from the Puna Ridge (inset). Bathymetry along the axis of the Puna Ridge and in the Hawaiian Moat at the distal end of the Puna Ridge after Lonsdale (1989), remainder of the bathymetry after Wilde et al. (1980), modified slightly based on data from U.S. Geological Survey cruise F2-88-HW (Clague et al. 1988). Dredge locations from Moore (1965) and Clague et al. (1985) are listed in table 1. Sample location symbols are: filled circle for dredges by Pioneer in 1962, filled triangles for dredges by Surveyor in 1966, filled squares for dredges by $R / V$ Farnella in 1988, and an open square for a box core by $R / V$ Farnella in 1988 that included five turbidite layers of submarine erupted glass sand and silt (these glasses are discussed in Clague et al. 1991).

at Cape Kumukahi to the east-northeast to a depth of roughly $5400 \mathrm{~m}$ (fig. 1). Lonsdale (1989) presented a detailed geomorphic analysis of the ridge based on high-resolution geophysical techniques and photography. This data set allows a more detailed interpretation than earlier work (Moore 1965; Moore and Fiske 1969; Fornari et al. 1978) and shows that the Puna Ridge is structurally similar to the subaerial portion of the east rift zone. In particular, it contains en-echelon eruptive fissures, pit craters, open fissures, grabens aligned along the axis of the rift, and small shields and steep-sided cones. The main difference between the submarine and subaerial portions of the rift is the steeper gradient along the axis of the submarine rift: the subaerial gradient of $23 \mathrm{~m} / \mathrm{km}$ steepens to $50 \mathrm{~m} /$ $\mathrm{km}$ near the shoreline and to $100 \mathrm{~m} / \mathrm{km}$ at a depth of about $2800 \mathrm{~m}$ (Lonsdale 1989).
Most of the rift zone consists of pillow lava flows and pillow joint-block talus (Moore and Fiske 1969; Fornari et al. 1978; Lonsdale 1989), although many of the dredged samples consist of flat to slightly curved slabs of lava with a glassy rim on the top, but not bottom, surface. These fragments are probably from hollow lava tubes in tube-fed lobate flows like the one illustrated by Fornari et al. (1978, fig. 8 bottom right). Lonsdale (1989) noted that sheet-like flows are more common along the deeper parts of the rift and dredge data confirm this observation (Clague et al. 1988).

\section{SAMPLE LOCATIONS}

Dredge locations and depths are listed in table 1 and shown in figure 1 except for dredges SU49-66 and SU51-66, located just south of the southern boundary of figure 1 . Along-rift dredges recovered samples (domi- 
TABLE 1

DREDGE LOCATIONS

\begin{tabular}{|c|c|c|c|}
\hline Dredge & Depth (m) & Lat. (N) & Long $(w)$ \\
\hline \multicolumn{4}{|l|}{ Along-Rift } \\
\hline 1684 & 490 & $19^{\circ} 32.1^{\prime}$ & $154^{\circ} 47.4^{\prime}$ \\
\hline 1717 & 550 & $19^{\circ} 32.7$ & $154^{\circ} 46.7$ \\
\hline D45 & 740 & $19^{\circ} 32.9^{\prime}$ & $154^{\circ} 45.4^{\prime}$ \\
\hline 1685 & 760 & $19^{\circ} 34.5^{\prime}$ & $154^{\circ} 45.5^{\prime}$ \\
\hline 1742 & 1400 & $19^{\circ} 36.5^{\prime}$ & $154^{\circ} 39.0^{\prime}$ \\
\hline SU56-66 & 1440 & $19^{\circ} 32.0^{\prime}$ & $154^{\circ} 429^{\prime}$ \\
\hline 1689 & 1600 & $19^{\circ} 36.5^{\prime}$ & $154^{\circ} 39.0^{\prime}$ \\
\hline 1688 & 1650 & $19^{\circ} 36.2^{\prime}$ & $154^{\circ} 42.8^{\prime}$ \\
\hline D43 & 1835 & $19^{\circ} 37.1^{\prime}$ & $154^{\circ} 36.3^{\prime}$ \\
\hline De2 & 2235 & $19^{\circ} 40.1^{\prime}$ & $154^{\circ} 29.9^{\prime}$ \\
\hline 1695 & 2590 & $19^{\circ} 42.5^{\prime}$ & $154^{\circ} 26.1^{\prime}$ \\
\hline 1697 & 2960 & $19^{\circ} 44.1^{\prime}$ & $154^{\circ} 24.5^{\prime}$ \\
\hline 1699 & 3410 & $19^{\circ} 45.2^{\prime}$ & $154^{\circ} 22.2^{\prime}$ \\
\hline 1701 & 3960 & $19^{\circ} 445^{\prime}$ & $154^{\circ} 15.0^{\prime}$ \\
\hline 1712 & 4680 & $19^{\circ} 50.2^{\prime}$ & $154^{\circ} 18.9^{\prime}$ \\
\hline 1706 & 5000 & $19^{\circ} 51.5^{\prime}$ & $154^{\circ} 15.2^{\prime}$ \\
\hline 1714 & 5180 & $19^{\circ} 49.1^{\prime}$ & $154^{\circ} 15.4^{\prime}$ \\
\hline D4 & 5470 & $19^{\circ} 49.6^{\circ}$ & $154^{\circ} 08.3^{\prime}$ \\
\hline D5 & 5490 & $19^{\circ} 26.9^{\prime}$ & $154^{\circ} 16.3^{\prime}$ \\
\hline \multicolumn{4}{|l|}{ Off-Rift } \\
\hline SU49-66 & 840 & $19^{\circ} 07.7$ & $155^{\circ} 16.5^{\prime}$ \\
\hline SU51-66 & 1040 & $19^{\circ} 12.6^{\circ}$ & $155^{\circ} 10.2^{\prime}$ \\
\hline SU57-66 & 1560 & $19^{\circ} 25.3^{\prime}$ & $154^{\circ} 48.9^{\circ}$ \\
\hline
\end{tabular}

NOTE-Dredges 1684 to 1742 recovered by the Pioncer in 1962; dredges SUxx-66 recovered by the Surveyor in 1966; dredges D4 to D45

recovered by $R / V$ Farmella in 1988.

nantly pillows) erupted in the submarine environment (table 1). The off-rift dredges recovered samples (dominantly glassy basaltic sand and scoria) from rubble-covered slopes of the volcano or from the submarine part of the 1960 Kapoho flow (table 1). The fragmental material sampled by the off-rift dredges is believed to be shattered, quenched lava formed by subaerial flows reaching the sea, and vitric ash formed by the phreatic processes (Moore and Fiske 1969). Thirteen of the dredges were recovered from the Puna Ridge by the Pioneer in 1962 (Moore 1965). Four dredges were recovered by the Surveyor in 1966; three of these are from the flanks of Kilauea and the fourth is located slightly off the axis of the Puna Ridge (Moore and Fiske 1969). The latest five dredges, recovered by the $R / V$ Farnella in 1988 , were located mainly to fill in gaps in the earlier dredge programs (Clague et al. 1988). One of these, D5, was recovered off the rift axis from a large inflated sheet flow that ponded in the Hawaiian Deep at the base of the Puna
Ridge and was discovered by a recent GLORIA side-scan sonar survey (Holcomb et al. 1988). Based on the GLORIA image this flow could have erupted from the Puna Ridge at any depth greater than about $4000 \mathrm{~m}$. One additional sample was collected by the submersible Makalii off the coast of Cape Kumikahi. Though the depth of collection is well known, an exact location is unavailable because of lack of reliable navigation during the dive. Several of the along-rift dredges (SU56, $1688, \mathrm{D} 43$, and 1714) are located slightly off the axis of the Puna Ridge and may have erupted up to $700 \mathrm{~m}$ shallower than the depths at which they were dredged. The uncertainty in eruption depth for these dredges is not large enough to significantly affect our conclusions.

Microprobe analyses of the glasses, petrography, and apparent age based on palagonite alteration were used to identify distinguishable flow units within individual dredges. Several flow units contain abundant crystal clusters ranging in size from large glomerocrysts to small gabbroic xenoliths about $1 \mathrm{~cm}$ in diameter that were also used to distinguish flow units. Most dredges recovered samples of only a single flow, but dredges D45, 1742, SU56-66, D43, and 1697 recovered two flow units, and D42 recovered three flow units.

\section{ANALYTICAL TECHNIQUES}

Modal analyses were performed on thin sections by point counting (1000 counts). Glass chips (1-3 mm in diameter) representative of each flow unit were selected for microprobe analysis, cast into epoxy mounts, and prepared as doubly-polished thin sections. The translucent, pale brown glassy rims were analyzed for major and minor elements on the 9-spectrometer ARL SEMQ microprobe at the U.S. Geological Survey, Menlo Park, using natural and synthetic standards (VG-2 for $\mathrm{SiO}_{2}, \mathrm{Al}_{2} \mathrm{O}_{3}, \mathrm{FeO}, \mathrm{MgO}, \mathrm{CaO}$, and $\mathrm{Na}_{2} \mathrm{O}$; orthoclase for $\mathrm{K}_{2} \mathrm{O}$; apatite for $\mathrm{P}_{2} \mathrm{O}_{5}$; barite for $\mathrm{S} ; \mathrm{TiO}_{2}$ for $\mathrm{TiO}_{2}$; and $\mathrm{Mn}_{2} \mathrm{O}_{3}$ for $\mathrm{MnO}$ ). Polished thin sections of glass inclusions in crystals were also prepared and analyzed. All glasses were analyzed using a slightly defocused beam (roughly $5 \mu \mathrm{m}$ spot size was used to avoid abundant phenocrysts and microphenocrysts), $10 \mathrm{nA}$ beam current, $15 \mathrm{kV}$ accelerating potential, and a total count time of $100 \mathrm{~s}$ for $\mathrm{S}, \mathrm{K}_{2} \mathrm{O}, \mathrm{P}_{2} \mathrm{O}_{5}$, and $\mathrm{Al}_{2} \mathrm{O}_{3}$, and $200 \mathrm{~s}$ 
for the remaining elements. Each analysis is the average of 3-5 point analyses of glasses from a single sample; many reported analyses are averages of multiple samples from the same flow unit, as indicated in tables 3 and 4. The use of barite as the standard for $S$ gives results about $15 \%$ lower than obtained using a sulfide (pyrrhotite or troilite) standard. This standard was used to improve agreement with previous results for samples from the same flow units analyzed by other techniques (see discussion in results section). Precision of the microprobe analyses is estimated from the means and standard deviations of 19 analyses of Juan de Fuca glass standard VG-2 and 15 analyses of Makoupuhi (Kilauea) glass standard A99 (table 2). Analyses of different glass chips from the same flow unit agree within the analytical precision.

Dissolved $\mathrm{H}_{2} \mathrm{O}$ and $\mathrm{CO}_{2}$ concentrations were determined by transmission infrared spectroscopy (FTIR) on doubly polished glass chips using the procedures and calibrations described by Dixon et al. (1988). This microbeam technique allows us to avoid vesicles, crystals, and areas of seawater alteration that may affect analyses of bulk samples. Where more than one spectrum was measured on glasses from the same flow unit, we report the average $\mathrm{H}_{2} \mathrm{O}$ content and standard deviation. Dissolved $\mathrm{H}_{2} \mathrm{O}$ concentrations based on two spectra from the same glass chip and from different glass chips from the same flow unit are reproducible to within $6 \%$ of the amount present. The intensities of the carbonate $\left(\mathrm{CO}_{3}^{2-}\right)$ peaks (1515 and 1435 $\mathrm{cm}^{-1}$ ) were measured separately after numerical subtraction of the spectrum of Kilauea Iki lava lake glass 79-6-190.3 (a glass containing no detectable dissolved $\mathrm{CO}_{2}$ ) and a concentration was calculated from the intensity of each peak. The dissolved $\mathrm{CO}_{2}$ contents are averages of all of the $\mathrm{CO}_{2}$ concentrations measured from all spectra on glass chips from the same flow unit. For samples with dissolved $\mathrm{CO}_{2}$ contents greater than $50 \mathrm{ppm}$, analyses on the same and different glass chips from the same flow unit are reproducible to within $8 \%$ of the amount present. Dissolved $\mathrm{CO}_{2}$ contents less than $50 \mathrm{ppm}$ are near the limits of detection and are reproducible to no better than about $70 \%$ of the amount present.

The accuracy of the reported $\mathrm{H}_{2} \mathrm{O}$ and $\mathrm{CO}_{2}$ concentrations is limited primarily by uncer-
TABLE 2

COMPARISON OF WET CHEMICAl AND MICROPROBE ANALYSES OF GLASS STANDARDS

\begin{tabular}{|c|c|c|c|c|}
\hline & $\overline{V G-2^{2}}$ & $\begin{array}{l}V G-2^{b} \\
n=19\end{array}$ & A- $99^{2}$ & $\begin{array}{l}A-99^{b} \\
n=15\end{array}$ \\
\hline $\begin{array}{l}\mathrm{SiO}_{2} \\
\mathrm{Al}_{2} \mathrm{O}_{3}\end{array}$ & $\begin{array}{l}50.81 \\
14.06\end{array}$ & $\begin{array}{l}50.56 \pm .30 \\
14.13 \pm .29\end{array}$ & $\begin{array}{l}50.94 \\
12.49\end{array}$ & $\begin{array}{r}51.00 \pm .43 \\
12.71 \pm .35\end{array}$ \\
\hline $\mathrm{FeO}^{*}$ & 11.84 & $11.69 \pm .10$ & 13.30 & $13.28 \pm .12$ \\
\hline $\mathrm{MnO}$ & .20 & $.21 \pm .01$ & .15 & $.20 \pm .01$ \\
\hline $\mathrm{MgO}$ & 6.71 & $6.99 \pm .05$ & 5.08 & $5.11 \pm .05$ \\
\hline $\mathrm{CaO}$ & 11.12 & $11.07 \pm .21$ & 9.30 & $9.26 \pm .18$ \\
\hline $\mathrm{Na}_{2} \mathrm{O}$ & 2.62 & $2.78 \pm .06$ & 266 & $2.80 \pm .05$ \\
\hline $\mathrm{K}_{2} \overline{\mathrm{O}}$ & .19 & $.19 \pm .01$ & .82 & $.82 \pm .03$ \\
\hline $\mathrm{P}_{2} \mathrm{O}_{5}$ & n.a. & $.22 \pm .02$ & n.a. & $.45 \pm .04$ \\
\hline $\mathrm{TiO}_{2}$ & 1.85 & $1.82 \pm .03$ & 4.06 & $3.99 \pm .06$ \\
\hline $\mathbf{S}$ & n.a. & $.134 \pm .008$ & n.a. & $.017 \pm .003$ \\
\hline
\end{tabular}

wet chemical analyses (Jarosewich et al. 1979)

bmean microprobe analysis and 1s standard deviation; The standard values for $\mathrm{SiO}_{2}, \mathrm{FeO}$, $\mathrm{MgO}_{8}$, and $\mathrm{Na}_{2} \mathrm{O}$ in VG-2 used in the microprobe data reduction program were modified slightly from the reported wet-chemical analysis based on microprobe analysis of VG-2 against other standards and are within the standard deviations reported for our mean analysis. n.a. = not analyzed

tainties in the molar absorption coefficients. These values are known to within $15 \%$ for the carbonate bands (Fine and Stolper 1986) and to about $10 \%$ for the hydroxyl band at $3535 \mathrm{~cm}^{-1}$ in basalts.

\section{RESULTS AND DISCUSSION OF DATA}

Microscopic Petrography.-All analyzed samples have glassy rims. The modal abundances in the along-rift samples (Table 3) are highly variable, but only three mineral assemblages are found: (1) olivine + clinopyroxene + spinel + glass; $(2)$ olivine + clinopyroxene + plagioclase + spinel + glass; and (3) olivine + clinopyroxene + plagioclase + orthopyroxene + spinel + glass. Four samples have assemblage (1), 10 have assemblage (2), and 12 have assemblage (3). The modal data demonstrate the crystal-rich character of many of the samples and the unusual occurrence of small amounts of clinopyroxene and plagioclase in olivine-rich $(>10 \%$ modal olivine) samples. Clague et al. (1991) present detailed mineral chemistry and whole-rock compositions of these lavas and discuss their formation processes. The glassy rinds of the 
TABLE 3

ANALYSES OF GLASSES FROM THE PUNA RIDCE

\begin{tabular}{|c|c|c|c|c|c|c|c|c|c|c|c|c|c|c|c|c|c|c|}
\hline $\begin{array}{l}\text { Flow Unit } \\
\text { Number } \\
\text { Depth (m) }\end{array}$ & $\begin{array}{r}1684 \\
1 \\
490 \\
\end{array}$ & $\begin{array}{r}1717 \\
2 \\
550 \\
\end{array}$ & $\begin{array}{r}45 a \\
2 \\
740 \\
\end{array}$ & $\begin{array}{r}45 b \\
5 \\
740 \\
\end{array}$ & $\begin{array}{r}1685 \\
2 \\
890 \\
\end{array}$ & $\begin{array}{r}1742 a \\
3 \\
1400 \\
\end{array}$ & $\begin{array}{r}1742 b \\
2 \\
1400 \\
\end{array}$ & $\begin{array}{r}\text { SU56a } \\
3 \\
1440 \\
\end{array}$ & $\begin{array}{r}\text { SU56b } \\
1 \\
1440 \\
\end{array}$ & $\begin{array}{r}1689 \\
1 \\
1600 \\
\end{array}$ & $\begin{array}{r}1688 \\
1 \\
1650 \\
\end{array}$ & $\begin{array}{r}\text { D43a } \\
3 \\
1835 \\
\end{array}$ & $\begin{array}{r}\text { D43b } \\
3 \\
1835 \\
\end{array}$ & $\begin{array}{r}742 a \\
7 \\
2235 \\
\end{array}$ & $\begin{array}{r}\mathrm{D} 42 \mathrm{~b} \\
2 \\
2235 \\
\end{array}$ & $\begin{array}{r}\text { D42c } \\
3 \\
2235 \\
\end{array}$ & $\begin{array}{r}1695 \\
1 \\
2590 \\
\end{array}$ & $\begin{array}{r}1697 \mathrm{a}^{\mathrm{d}} \\
2 \\
2960 \\
\end{array}$ \\
\hline $\mathrm{SiO}_{2}$ & 51.2 & 51.8 & 50.7 & 51.0 & 50.7 & 52.2 & 50.0 & 52.0 & 52.2 & 51.8 & 51.4 & 51.0 & 51.9 & 51.2 & 50.9 & 51.0 & 51.6 & 52.4 \\
\hline $\begin{array}{l}\mathrm{Al}_{2} \mathrm{O}_{3} \\
\mathrm{FeO}\end{array}$ & $\begin{array}{l}14.2 \\
11.0\end{array}$ & $\begin{array}{l}13.6 \\
11.3\end{array}$ & $\begin{array}{l}14.1 \\
11.2\end{array}$ & $\begin{array}{l}13.8 \\
11.4\end{array}$ & $\begin{array}{l}13.6 \\
11.6\end{array}$ & $\begin{array}{l}13.5 \\
10.9\end{array}$ & $\begin{array}{l}13.8 \\
11.0\end{array}$ & $\begin{array}{l}14.1 \\
10.4\end{array}$ & $\begin{array}{l}14.2 \\
10.9\end{array}$ & $\begin{array}{l}13.6 \\
11.4\end{array}$ & $\begin{array}{l}13.7 \\
11.3\end{array}$ & $\begin{array}{l}14.2 \\
10.2\end{array}$ & $\begin{array}{l}13.6 \\
11.8\end{array}$ & $\begin{array}{l}14.0 \\
10.8\end{array}$ & $\begin{array}{l}13.8 \\
11.2\end{array}$ & $\begin{array}{l}14.4 \\
10.9\end{array}$ & $\begin{array}{l}13.8 \\
10.5\end{array}$ & $\begin{array}{l}13.7 \\
11.1\end{array}$ \\
\hline $\mathrm{MnO}$ & .15 & .16 & .17 & .17 & .18 & .16 & .17 & .15 & .16 & .16 & .18 & .16 & .18 & .17 & .16 & .17 & .16 & .15 \\
\hline $\mathrm{MgO}$ & 6.37 & 5.98 & 6.00 & 5.86 & 6.07 & 6.39 & 6.41 & 6.70 & 5.62 & 5.20 & 6.20 & 6.96 & 5.65 & 6.50 & 6.28 & 6.49 & 6.45 & 6.25 \\
\hline $\mathrm{CaO}$ & 10.9 & 10.2 & 10.6 & 10.0 & 10.3 & 10.3 & 10.8 & 10.9 & 9.63 & 9.23 & 10.4 & 11.1 & 9.79 & 10.7 & 10.5 & 10.7 & 10.6 & 10.4 \\
\hline $\mathrm{Na}_{2} \mathrm{O}$ & 2.48 & 2.56 & 2.69 & 2.67 & 2.71 & 2.52 & 2.59 & 2.53 & 2.83 & 2.72 & 2.46 & 2.40 & 2.67 & 2.44 & 2.53 & 2.60 & 2.53 & 2.62 \\
\hline $\mathrm{K}_{2} \mathrm{O}$ & .52 & .54 & .49 & .58 & .67 & .46 & .52 & .48 & .67 & .67 & .47 & .41 & .53 & .41 & .52 & .48 & .50 & .46 \\
\hline $\mathrm{P}_{2} \mathrm{O}_{5}$ & .33 & .37 & .32 & .32 & .40 & .31 & .32 & .30 & .41 & .48 & .31 & .27 & .33 & .28 & .36 & .30 & .29 & .27 \\
\hline $\begin{array}{l}\mathrm{TiO}_{2} \\
\text { Total }\end{array}$ & $\frac{2.70}{99.9}$ & $\frac{2.87}{99.5}$ & $\frac{2.72}{99.0}$ & $\frac{3.00}{98.9}$ & $\frac{3.16}{99.5}$ & $\frac{2.80}{99.6}$ & $\frac{2.78}{98.5}$ & $10 \frac{2.59}{0.2}$ & $\frac{3.10}{99.8}$ & $\frac{3.22}{98.6}$ & $\frac{2.76}{99.3}$ & $\frac{2.42}{99.2}$ & $\frac{3.20}{99.8}$ & $\frac{2.49}{99.1}$ & $\frac{2.72}{99.1}$ & $\frac{2.69}{99.8}$ & $\frac{2.63}{99.2}$ & $\frac{2.81}{100.2}$ \\
\hline$S$ (wt \%) & .066 & .073 & .098 & .100 & .090 & .022 & .125 & .047 & .098 & .129 & .123 & .098 & .144 & .117 & .119 & .085 & .104 & .073 \\
\hline $\mathrm{H}_{2} \mathrm{O}(w t \%)^{a}$ & .47 & .38 & .50 & .42 & .40 & .11 & .48 & .22 & .54 & .81 & .51 & .48 & .58 & .61 & .62 & $\ldots$ & .57 & $\ldots$ \\
\hline std. dev. & $\ldots$ & .04 & $\ldots$ & $\ldots$ & .01 & $\ldots$ & $\ldots$ & .01 & .04 & .02 & $\ldots$ & $\ldots$ & .07 & $\ldots$ & $\ldots$ & $\ldots$ & $\ldots$ & $\ldots$ \\
\hline $\mathrm{CO}_{2}(\mathrm{ppm})^{\mathrm{b}}$ & 0 & 0 & 30 & 19 & 29 & 0 & 39 & 71 & 46 & 0 & 57 & 84 & 21 & 117 & 110 & $\ldots$ & 118 & $\ldots$ \\
\hline std. dev. & $\ldots$ & $\ldots$ & 20 & 5 & 15 & $\ldots$ & 11 & 7 & 10 & 0 & 8 & 5 & 13 & 10 & 17 & $\ldots$ & 30 & $\ldots$ \\
\hline \multicolumn{19}{|c|}{ Modal Analysesc } \\
\hline Vesicles & 32.9 & 15.8 & .7 & 9.8 & 10.9 & 0 & 7.4 & 2.8 & 1.4 & 4.0 & 2.0 & 1.7 & 0.3 & .1 & 1.7 & .7 & .7 & .6 \\
\hline Olivine & 1 & 6 & 3 & 5 & 5 & 18 & 6 & 9 & 29 & 10 & 5 & 28 & 12 & 7 & 6 & 3 & 9 & 7 \\
\hline$C_{p x}$ & 2 & 6 & 3 & 4 & 4 & 1 & 2 & 1 & 2 & 5 & 2 & $<1$ & 10 & $<1$ & 2 & 1 & $<1$ & 4 \\
\hline Opx & $\ldots$ & $>1$ & $\ldots$ & $>1$ & 2 & $\ldots$ & $\ldots$ & $\ldots$ & $>1$ & $<1$ & $\ldots$ & $\ldots$ & $<1$ & $\ldots$ & $\ldots$ & $\ldots$ & $<1$ & $<1$ \\
\hline Plag & $<1$ & 4 & 2 & 3 & 5 & $<1$ & 1 & $<1$ & 1 & 4 & $\dddot{1}$ & $\ldots$ & 11 & 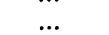 & 2 & $<1$ & $<1$ & 5 \\
\hline
\end{tabular}

"Calculated using molar absorption coefficient of $63 \pm 51 \mathrm{~mol}^{-1} \mathrm{~cm}^{-1}$ for the $3535 \mathrm{~cm}^{-1}$ band in basalt (P. Dobson, $S$. Newman, S. Epstein, and E Stolper, unpublished results) and assumed glass density of $2.8 \mathrm{~g} \mathrm{~cm}^{-3}$. Where more than one spectrum was measured we report the average and atandard deviation.

The intensities of the carbonate $\left(\mathrm{CO}_{3}{ }^{2}\right)$ peaks $\left(1515-1435 \mathrm{~cm}^{-1}\right)$ were messured separately after numerical subtraction of the spectrum of Kilauea Iki lava lake glass 79-6-190.3 (a glass containing no detectable diseolved $\mathrm{CO}_{2}$ ) and a concentration was calculated from each measurement using a molar absorption coefficient of $375 \mathrm{l} \mathrm{mol}^{-1} \mathrm{~cm}^{-1}$ (Fine and Stolper 1986) and an asoumed giass density of $2.8 \mathrm{~g} \mathrm{~cm}^{-3}$. The dissolved $\mathrm{CO}_{2}$ contents are averages of all of the $\mathrm{CO}_{2}$ concentrations mensured from all spectra on glass chips from the same split.

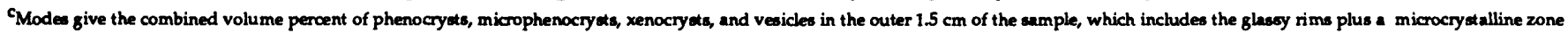
adjacent to the glasoy rim. All samples contain <1\% chromite encloeed in olivine phenoctysta.

dSample 1697 analyzed by Killingley and Muenow (1975) and Muenow al (1979) is from flow unit 1697a. Sample 1697 analyzed by Byers et al (1985) and Harris (1981) is probably from flow unit 1697b. Sample reported as $1712(4680 \mathrm{~m}$ ) by Byers et al (1985) is probably a misidentified sample from dredge 1714 based on their reported microprobe gless analysis. 
TABLE 3 (cont)

ANALYSES OF GLASSES FROM THE PUNA RIDGE

\begin{tabular}{|c|c|c|c|c|c|c|c|c|}
\hline $\begin{array}{l}\text { Flow Unit } \\
\text { Number } \\
\text { Depth (m) }\end{array}$ & $\begin{array}{r}1697 \mathrm{~b} \\
2 \\
2960 \\
\end{array}$ & $\begin{array}{r}1699 \\
2 \\
3420 \\
\end{array}$ & $\begin{array}{r}1701 \\
1 \\
3970 \\
\end{array}$ & $\begin{array}{r}1712^{d} \\
4 \\
4680 \\
\end{array}$ & $\begin{array}{r}1706 \\
2 \\
5000 \\
\end{array}$ & $\begin{array}{r}1714^{d} \\
1 \\
5190 \\
\end{array}$ & $\begin{array}{r}\text { D4 } \\
13 \\
5470 \\
\end{array}$ & $\begin{array}{r}\text { D5 } \\
8 \\
5490 \\
\end{array}$ \\
\hline $\mathrm{SiO}_{2}$ & 52.5 & 51.9 & 51.2 & 51.4 & 51.9 & 51.4 & 50.6 & 51.1 \\
\hline $\begin{array}{l}\mathrm{Al}_{2} \mathrm{O}_{3} \\
\mathrm{FeO}\end{array}$ & $\begin{array}{l}13.9 \\
10.5\end{array}$ & $\begin{array}{l}13.9 \\
11.1\end{array}$ & $\begin{array}{l}13.4 \\
11.2\end{array}$ & $\begin{array}{l}13.7 \\
11.5\end{array}$ & $\begin{array}{l}14.0 \\
11.0\end{array}$ & $\begin{array}{l}13.8 \\
10.9\end{array}$ & $\begin{array}{l}14.2 \\
11.0\end{array}$ & $\begin{array}{l}14.3 \\
10.3\end{array}$ \\
\hline $\begin{array}{l}\mathrm{MnO} \\
\mathrm{MpO}\end{array}$ & $\begin{array}{l}0.16 \\
6.64\end{array}$ & .15 & .16 & .16 & .15 & .17 & .17 & $\begin{array}{r}.17 \\
656\end{array}$ \\
\hline $\begin{array}{l}\mathrm{MgO} \\
\mathrm{CaO}\end{array}$ & $\begin{array}{c}6.64 \\
10.6\end{array}$ & $\begin{array}{l}5.60 \\
9.68\end{array}$ & $\begin{array}{l}5.40 \\
9.27\end{array}$ & $\begin{array}{l}5.84 \\
9.85\end{array}$ & $\begin{array}{l}5.65 \\
9.88\end{array}$ & $\begin{array}{c}6.42 \\
10.4\end{array}$ & $\begin{array}{c}6.56 \\
10.6\end{array}$ & $\begin{array}{c}6.56 \\
10.6\end{array}$ \\
\hline $\mathrm{Na}_{2} \mathrm{O}$ & 2.52 & 2.75 & 2.77 & 2.66 & 2.71 & 2.61 & 2.56 & 2.54 \\
\hline $\mathrm{K}_{2} \mathrm{O}$ & 0.41 & .66 & .68 & .62 & .55 & .51 & .48 & .47 \\
\hline $\begin{array}{l}\mathrm{P}_{2} \mathrm{O}_{5} \\
\mathrm{TiO}_{2} \\
\text { Total }\end{array}$ & $\begin{array}{r}0.25 \\
2.55 \\
100.1\end{array}$ & $\begin{array}{r}.41 \\
\underline{3.13} \\
99.4\end{array}$ & $\begin{array}{r}.42 \\
\frac{3.30}{97.9}\end{array}$ & $\begin{array}{r}.38 \\
\frac{3.18}{99.4}\end{array}$ & $\begin{array}{r}.39 \\
\frac{3.09}{99.4}\end{array}$ & $\begin{array}{r}.30 \\
\frac{2.86}{99.5}\end{array}$ & $\begin{array}{r}.28 \\
\frac{2.75}{99.3}\end{array}$ & $\begin{array}{r}.25 \\
\frac{2.60}{99.0}\end{array}$ \\
\hline$S$ (wt \%) & .067 & .125 & .127 & .109 & .120 & .108 & .087 & .077 \\
\hline $\mathrm{H}_{2} \mathrm{O}(w t)^{a}$ & .24 & .85 & .61 & .53 & .74 & .44 & .46 & .63 \\
\hline std. dev. & .01 & .05 & $\ldots$ & .01 & ... & $\ldots$ & .04 & .01 \\
\hline $\mathrm{CO}_{2}(\mathrm{ppm})^{\mathrm{b}}$ & 117 & 144 & 113 & 183 & 220 & 246 & 278 & 263 \\
\hline std. dev. & 20 & 30 & 5 & 9 & 5 & 27 & 20 & 22 \\
\hline \multicolumn{9}{|c|}{ Modal Analyseg } \\
\hline Vesicles & 1.0 & 1.5 & .2 & .5 & .0 & .0 & .6 & .5 \\
\hline Olivine & 17 & 19 & 29 & 14 & 22 & 12 & 15 & 24 \\
\hline Cpx & 1 & 6 & 5 & 4 & 5 & 4 & 1 & 1 \\
\hline Opx & $\ldots$ & $<1$ & $<1$ & $<1$ & $\cdots$ & $<1$ & $\cdots$ & ... \\
\hline Plag & 1 & 5 & 3 & 3 & 1 & 2 & 1 & $\ldots$ \\
\hline
\end{tabular}

TABLE 4

Migroprobe ANALYSES OP SURABRIALIY ERUPTED KTAURAN GIASSES

\begin{tabular}{|c|c|c|c|c|c|c|c|}
\hline $\begin{array}{l}\text { Flow Unit } \\
\text { Number } \\
\text { Depth }\end{array}$ & $\begin{array}{r}228-3^{3} \\
1 \\
220 \\
\end{array}$ & $\begin{array}{r}\text { SU49 } \\
1 \\
840 \\
\end{array}$ & $\begin{array}{r}\text { SU51a } \\
1 \\
1040 \\
\end{array}$ & $\begin{array}{r}\text { SU51b } \\
1 \\
1040 \\
\end{array}$ & $\begin{array}{r}\text { SU57a } \\
1 \\
1560 \\
\end{array}$ & $\begin{array}{r}\text { SU57b } \\
1 \\
1560 \\
\end{array}$ & $\begin{array}{r}\text { SU57c } \\
1 \\
1560 \\
\end{array}$ \\
\hline $\mathrm{SiO}_{2}$ & 50.6 & 51.5 & 51.3 & 52.0 & 52.1 & 51.4 & 51.2 \\
\hline $\mathrm{Al}_{2} \mathrm{O}_{3}$ & 13.5 & 13.3 & 14.0 & 13.8 & 13.6 & 13.2 & 13.7 \\
\hline $\mathrm{FeO}$ & 11.3 & 11.8 & 10.9 & 11.0 & 11.1 & 12.0 & 11.8 \\
\hline $\mathrm{MnO}$ & .20 & 19 & .16 & .16 & .15 & .18 & .18 \\
\hline $\mathrm{MgO}$ & 5.25 & 6.32 & 6.93 & 6.58 & 6.45 & 6.10 & 6.07 \\
\hline $\mathrm{CaO}$ & 9.44 & 10.8 & 11.2 & 11.3 & 11.2 & 10.6 & 10.3 \\
\hline $\mathrm{Na}_{2} \mathrm{O}$ & 2.84 & 2.47 & 2.40 & 2.42 & 2.50 & 2.64 & 2.61 \\
\hline $\mathrm{K}_{2} \mathrm{O}$ & .95 & .49 & .46 & .44 & .45 & .53 & .58 \\
\hline $\mathrm{P}_{2} \mathrm{O}_{5}$ & .56 & .30 & .32 & .25 & .28 & .31 & .39 \\
\hline $\mathrm{TiO}_{2}$ & $\underline{4.28}$ & $\underline{2.90}$ & 2.46 & $\underline{2.52}$ & $\underline{2.66}$ & $\underline{2.96}$ & $\underline{3.13}$ \\
\hline Total & 98.9 & 100.1 & 100.1 & 100.5 & 100.5 & 99.9 & 100.0 \\
\hline$S(w t . \%)$ & .024 & .015 & .007 & .011 & .017 & .013 & .01 \\
\hline $\mathrm{H}_{2} \mathrm{O}$ (wt. \%) & $\ldots$ & $\ldots$ & $\ldots$ & .09 & $\ldots$ & .09 & $\ldots$ \\
\hline std.dev. & ... & $\ldots$ & ... & .00 & $\ldots$ & .00 & ... \\
\hline $\mathrm{CO}_{2}$ (ppm) & $\ldots$ & $\ldots$ & $\ldots$ & 0 & $\cdots$ & 0 & $\cdots$ \\
\hline std.dev. & $\ldots$ & $\ldots$ & $\ldots$ & 0 & $\ldots$ & 0 & $\ldots$ \\
\hline
\end{tabular}

" 1960 Kapoho flow collected off Cape Kumikahi by the submersible Makali' $i$ on dive PPB2-228 as sample 3. 
off-rift samples contain abundant microlites and are texturally distinct from the other submarine samples. This texture is typical of subaerially degassed lavas that have quenched below sealevel (see discussion in Moore and Clague 1987).

Olivine, and less commonly plagioclase, clinopyroxene, and orthopyroxene phenocrysts contain translucent, pale brown glass inclusions. Glass inclusions up to about 200 $\mu \mathrm{m}$ in diameter are present in both euhedral and resorbed phenocrysts. Many of the inclusions in olivine contain single euhedral crystals of Cr-rich spinel, and some include a small vapor bubble. No sulfide phase was seen in any inclusions. $\mathrm{CO}_{2}$-rich fluid inclusions in olivine, like those observed in dunite xenoliths from Hawaii (Roedder 1965), were not observed.

Moore (1965) studied a subset of these samples and showed that down to depths of $800 \mathrm{~m}$, Puna Ridge basalts have $>10 \%$ vesicles and bulk densities $<2.8 \mathrm{~g} / \mathrm{cm}^{3}$. Below $800 \mathrm{~m}$ the vesicles become smaller and less abundant and the bulk densities increase slowly with depth from 2.8 to $3.0 \mathrm{~g} / \mathrm{cm}^{3}$. Our modal data, when uncertainties in eruption depth are considered, support his observations. The vesicle content is $<2 \mathrm{vol} \%$ at 2000-5500 m depth. At shallower levels, vesicle content increases with decreasing depth to nearly $35 \mathrm{vol} \%$ in a lava collected at $490 \mathrm{~m}$.

Major and Minor Elements.-The glassy rims analyzed in this study are tholeiitic in composition and have low ( $\leq 7 \mathrm{wt} \%) \mathrm{MgO}$ contents (tables 3 and 4). Glass compositions are uncorrelated with eruption depth and more, and less fractionated samples occur with equal frequency at all depths. Glass compositions of the along-rift samples are plotted on $\mathrm{MgO}$-variation diagrams in figure 2 with model liquid lines of descent calculated using the procedures of Grove and Baker (1984) (see caption of fig. 2 for details). The compositions of the off-rift samples are similar to those of the along-rift samples. $\mathrm{Al}_{2} \mathrm{O}_{3}$ and $\mathrm{CaO}$ contents decrease with decreasing $\mathrm{MgO}$ content, whereas $\mathrm{FeO}^{*}, \mathrm{Na}_{2} \mathrm{O}, \mathrm{K}_{2} \mathrm{O}, \mathrm{P}_{2} \mathrm{O}_{5}$, and $\mathrm{TiO}_{2}$ contents increase with decreasing $\mathrm{MgO}$ content. The $\mathrm{FeO}^{*}$ contents of the most fractionated samples $(\mathrm{MgO}<5.5 \mathrm{wt} \%)$ are lower and their $\mathrm{P}_{2} \mathrm{O}_{5}$ and $\mathrm{K}_{2} \mathrm{O}$ contents are higher than the values expected based on the calculated liquid line of descent. The analytical errors for $\mathrm{SiO}_{2}(1 \sigma=0.30-0.43)$ are large enough to mask any trends that may be present. Analyses of $\mathrm{Na}_{2} \mathrm{O}, \mathrm{P}_{2} \mathrm{O}_{5}, \mathrm{Al}_{2} \mathrm{O}_{3}$, and $\mathrm{CaO}$ are generally within error of subaerial lavas with similar MgO contents (Wright and Fiske 1971). At the same $\mathrm{MgO}$ content, our $\mathrm{SiO}_{2}$ analyses are higher, and our $\mathrm{FeO}, \mathrm{TiO}_{2}$, and $\mathrm{K}_{2} \mathrm{O}$ analyses are lower than those of Wright and Fiske (1971).

The $\mathrm{K}_{2} \mathrm{O} / \mathrm{P}_{2} \mathrm{O}_{5}$ ratio for the glasses included in this study is nearly constant with an average and $1 \sigma$ value of $1.61 \pm 0.12$ (fig. 3 ). Whole-rock XRF analyses of many of the same samples gave an average $\mathrm{K}_{2} \mathrm{O} / \mathrm{P}_{2} \mathrm{O}_{5}$ ratio of $1.79 \pm 0.07$ (Clague et al. 1990), similar to values determined by wet-chemistry on whole-rock samples for prehistoric Kilauean lavas $(1.70 \pm 0.06)$ and the 1840 Kilauea picrite $(1.84 \pm 0.0)$, but lower than the $1959 \mathrm{Ki}$ lauea Iki lavas $(2.05 \pm 0.06)$ (Wright 1971). Variations in incompatible element ratios comparable in magnitude to these variations in $\mathrm{K}_{2} \mathrm{O} / \mathrm{P}_{2} \mathrm{O}_{5}$ in lavas from many different eruptions of Kilauea have been observed during a single sustained eruption of Mauna Ulu (Hofmann et al. 1984).

Dissolved $\mathrm{H}_{2} \mathrm{O}$.- - Dissolved $\mathrm{H}_{2} \mathrm{O}$ contents in along-rift glasses range from 0.11 to 0.85 wt $\%$. Dissolved $\mathrm{H}_{2} \mathrm{O}$ contents in the two offrift (subaerially degassed) glasses analyzed by FTIR are 0.09 wt $\%$. Flow 1742a has an $\mathrm{H}_{2} \mathrm{O}$ content $(0.11 \mathrm{wt} \%)$ similar to those of these subaerial samples, even though it was dredged along the axis of the Puna Ridge at a depth of $1400 \mathrm{~m}$. Samples having dissolved $\mathrm{H}_{2} \mathrm{O}$ contents $<0.35$ wt $\%$ contain only $\mathrm{OH}^{-}$ groups. Based on the presence of an absorption at $1630 \mathrm{~cm}^{-1}$ in glasses with total water contents $>0.35 \mathrm{wt} \%$, we conclude that both molecular $\mathrm{H}_{2} \mathrm{O}$ and $\mathrm{OH}^{-}$groups are present in these glasses. The molar absorption coefficient for the molecular water band at 1630 $\mathrm{cm}^{-1}$ in basaltic glass is not well known, but using the values for rhyolitic and albitic glasses (Newman et al. 1986; Silver and Stolper 1989), we estimate that no more than $10 \%$ of the total dissolved water is present as molecular $\mathrm{H}_{2} \mathrm{O}$. Dissolved molecular $\mathrm{H}_{2} \mathrm{O}$ is present in Kilauean tholeiitic glasses at slightly lower total $\mathrm{H}_{2} \mathrm{O}$ contents than in mid-ocean ridge basalt (MORB) glasses; for example, no molecular $\mathrm{H}_{2} \mathrm{O}$ was detected in 


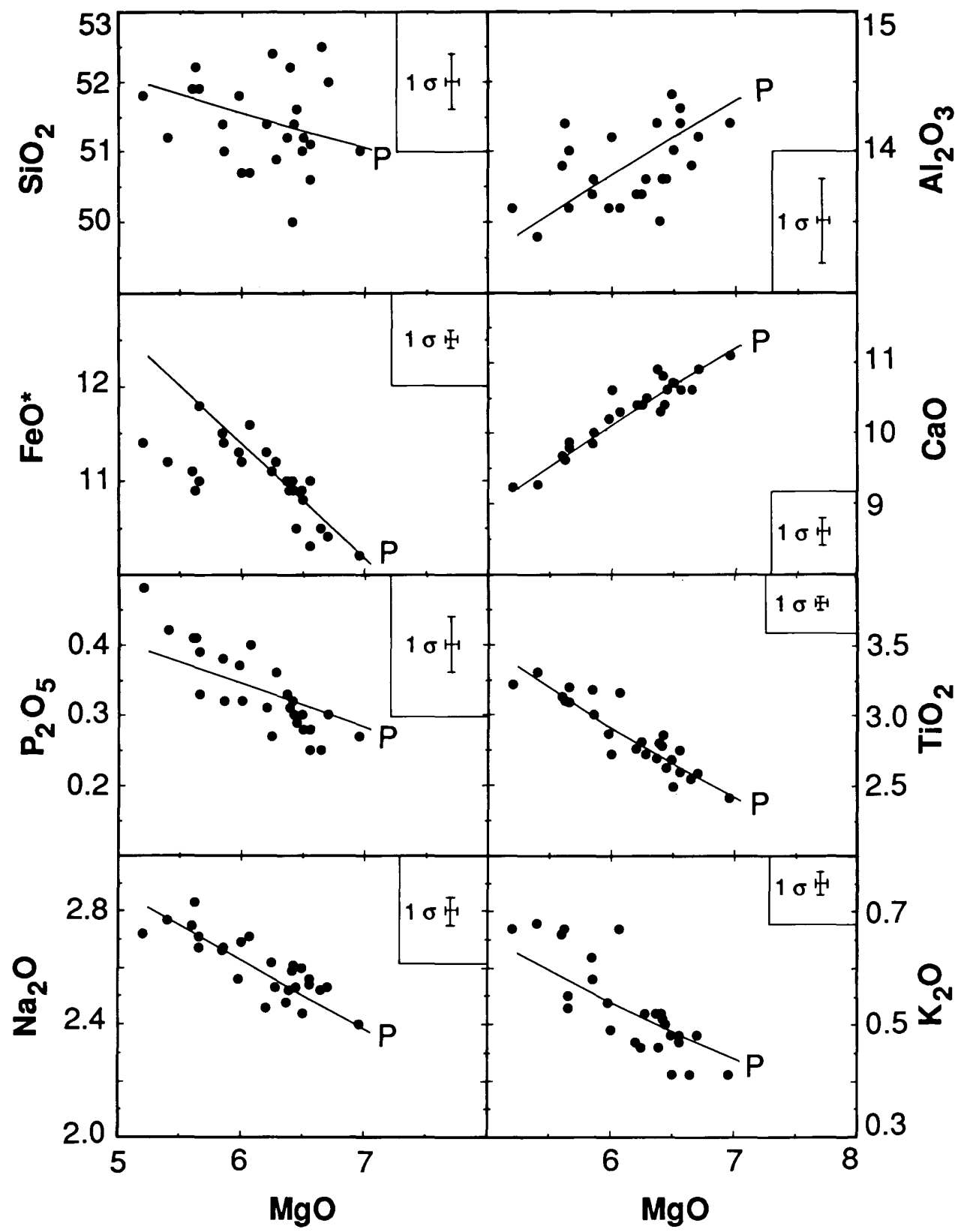

FIG. 2.- MgO variation diagrams of glass compositions from the Puna Ridge. Solid line represents $0-30 \%$ crystal fractionation of olivine, plagioclase, and clinopyroxene in proportions of 1:5.2:4.9 from a parental magma (P). Composition of parental magma (in wt \%) is $\mathrm{SiO}_{2}$ 51.02, $\mathrm{Al}_{2} \mathrm{O}_{3}$ 14.37, $\mathrm{FeO} 10.12, \mathrm{MnO} 0.13$, $\mathrm{MgO} 7.00, \mathrm{CaO} 11.23, \mathrm{Na}_{2} \mathrm{O} 2.37, \mathrm{~K}_{2} \mathrm{O} 0.44, \mathrm{P}_{2} \mathrm{O}_{5} 0.28, \mathrm{TiO}_{2} 2.40, \mathrm{~S} 0.120, \mathrm{H}_{2} \mathrm{O} 0.62, \mathrm{CO}_{2} 0.048$. Fractional crystallization calculations (following Grove and Baker 1984) were carried out in increments by removing $2 \mathrm{wt} \%$ solids from an initial liquid to give a residual fractionated liquid. Compositions of olivine, plagioclase, and clinopyroxene in equilibrium with the initial liquid were calculated for each increment using Fe-Mg distribution coefficients of 0.30 for olivine (Roedder 1974) and 0.25 for clinopyroxene (Grove and Bryan 1983) and $\mathrm{Ca}-\mathrm{Na}$ distribution coefficient of 1.5 for plagioclase. The $\mathrm{CaO}, \mathrm{Al}_{2} \mathrm{O}_{3}$, and $\mathrm{TiO}_{2}$ contents of the clinopyroxene were kept constant at $19.1,2.49,0.65 \mathrm{wt} \%$, respectively, and were chosen to be close to the average composition found in lavas from the Puna Ridge (Clague et al. 1991). 


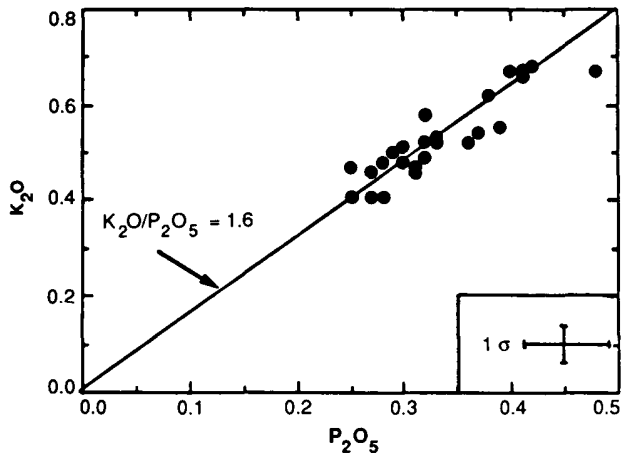

FIG. 3. $-\mathrm{K}_{2} \mathrm{O}$ vs. $\mathrm{P}_{2} \mathrm{O}_{5}$ for the glass compositions from the Puna Ridge.

glasses from the Juan de Fuca Ridge having dissolved $\mathrm{H}_{2} \mathrm{O}$ contents up to 0.48 wt $\%$ (Dixon et al. 1988).

Water concentrations in samples from a few of the same dredges analyzed in this study have been analyzed previously by other techniques. The data of Moore (1965) and Kyser and O'Neil (1984) have been corrected for the mass fraction of phenocrysts in their whole-rock samples using our modal data (see caption to fig. 4). In general there is good agreement between the different data sets (fig. 4a). Almost all the $\mathrm{H}_{2} \mathrm{O}$ concentrations measured by Moore (1965) using the Penfield method, Harris (1981) and Kyser and O-Neil (1984) using vacuum fusion/manometry, and Killingley and Muenow (1975) and Muenow et al. (1979) using vacuum fusion/ mass spectrometry on glass separates, are within $30 \%$ of our values. However, the analysis of sample 1712 by Harris (1981) is $57 \%$ lower than ours, and the analysis of 1717 by Moore (1965) is $70 \%$ higher than ours.

$\mathrm{H}_{2} \mathrm{O}$ contents show a weak correlation with depth (fig. 5a) that is unrelated to the solubility curve for pure water in basalt at $1100^{\circ} \mathrm{C}$ based on an extrapolation of the high pressure data of Hamilton et al. (1964) to the low pressures relevant to these depths of eruption. Nearly the entire range of $\mathrm{H}_{2} \mathrm{O}$ values occurs within the depth range of 1400 to 1600 $\mathrm{m}$. Samples erupted in water depths shallower than $1000 \mathrm{~m}$ fall near the solubility curve (Hamilton et al. 1964) and are probably saturated with respect to water. These samples, however, are not the ones with the lowest $\mathrm{H}_{2} \mathrm{O}$ contents. Samples erupted deeper
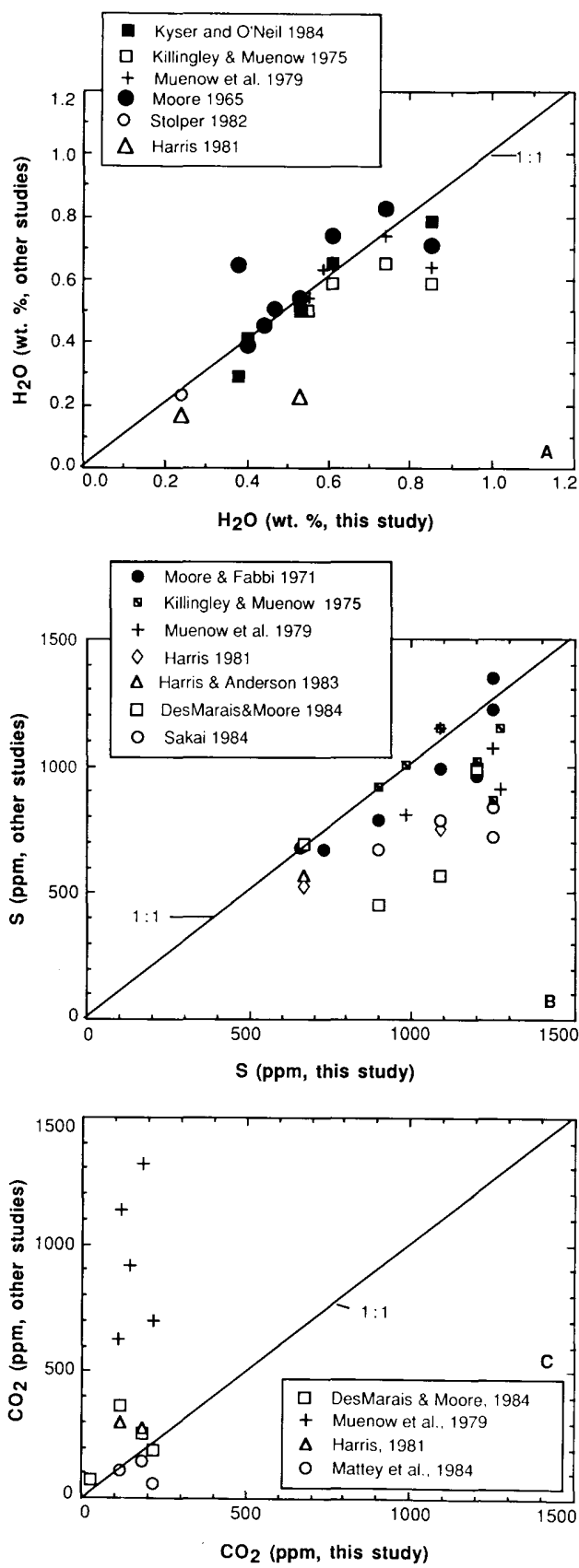

FIG. 4.-Comparisons of volatile element data measured by other techniques and those reported in this study on samples from the same flow units. Filled symbols represent analyses of glassy wholerock samples. $\mathrm{H}_{2} \mathrm{O}$ and $\mathrm{S}$ concentrations shown on the figure for whole-rock samples have been corrected for the mass fraction of phenocrysts using our modal data (table 3) and densities $\left(\mathrm{g} / \mathrm{cm}^{3}\right)$ of 3.5 for olivine, 3.3 for clinopyroxene, and 2.72 for plagioclase. Open symbols and crosses represent analyses of glass separates. (a) $\mathrm{H}_{2} \mathrm{O},(b) \mathrm{S},(c) \mathrm{CO}_{2}$. 

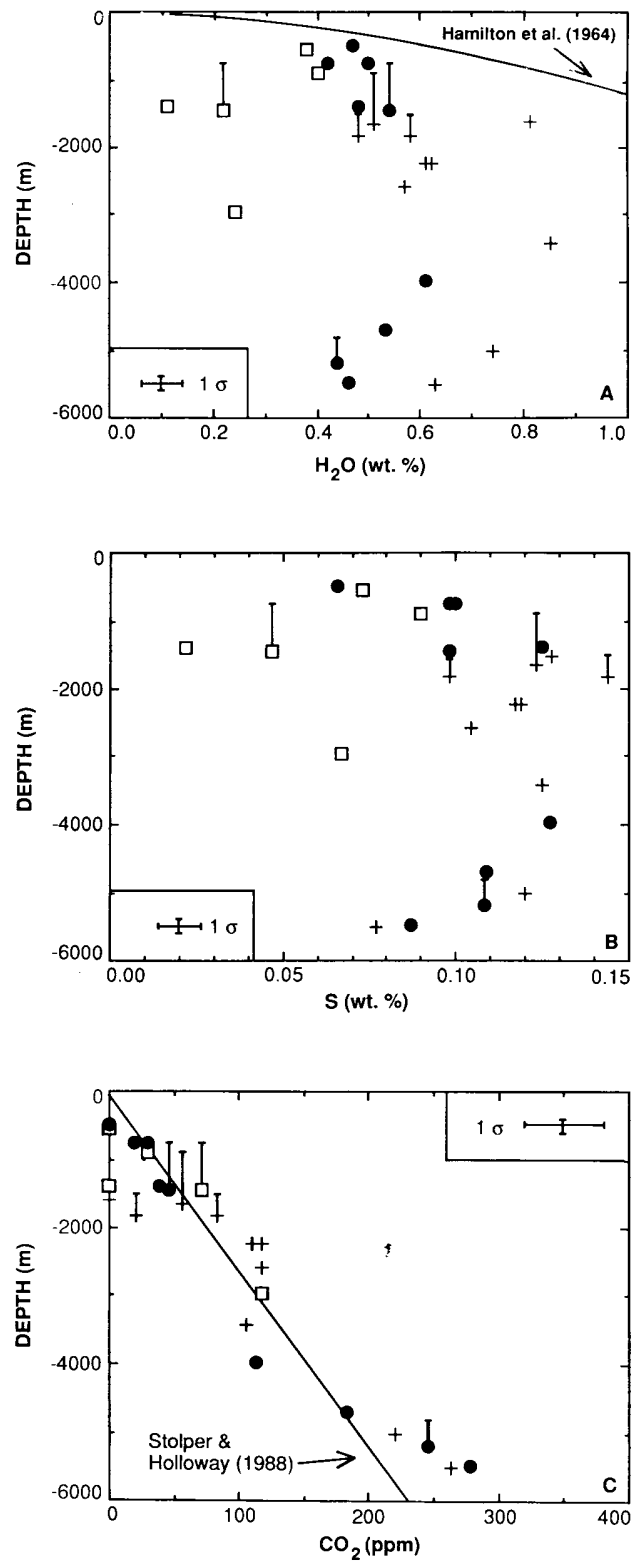

FIG. 5.-(a) Dissolved $\mathrm{H}_{2} \mathrm{O}$ vs. depth. Solubility of pure $\mathrm{H}_{2} \mathrm{O}$ in basalt at $1100^{\circ} \mathrm{C}$ (Hamilton et al. 1964) is an extrapolation of higher pressure data. (b) Dissolved S vs. depth. (c) Dissolved $\mathrm{CO}_{2}$ vs. depth. Open squares: low $-\mathrm{H}_{2} \mathrm{O} / \mathrm{K}_{2} \mathrm{O}$ samples with $\mathrm{H}_{2} \mathrm{O} / \mathrm{K}_{2} \mathrm{O}$ ratios $\leq 0.7$; Filled circles: moderate$\mathrm{H}_{2} \mathrm{O} / \mathrm{K}_{2} \mathrm{O}$ samples with $\mathrm{H}_{2} \mathrm{O} / \mathrm{K}_{2} \mathrm{O}$ ratios between 0.7 and 1.0; Crosses: high- $\mathrm{H}_{2} \mathrm{O} / \mathrm{K}_{2} \mathrm{O}$ samples with $\mathrm{H}_{2} \mathrm{O} / \mathrm{K}_{2} \mathrm{O}>1.0$. Vertical lines through some symbols show uncertainty in depth of eruption. than $1000 \mathrm{~m}$ are greatly undersaturated with respect to pure water.

$\mathrm{H}_{2} \mathrm{O}$ contents are plotted vs. $\mathrm{MgO}$ and $\mathrm{K}_{2} \mathrm{O}$ contents in figure $6 a$ and $b$. In general, $\mathrm{H}_{2} \mathrm{O}$ contents increase with decreasing $\mathrm{MgO}$ and increasing $\mathrm{K}_{2} \mathrm{O}$ contents, but the scatter in the $\mathrm{H}_{2} \mathrm{O}$ data is two to three times greater than in the $\mathrm{K}_{2} \mathrm{O}$ data at a given $\mathrm{MgO}$ content (fig. 2). The observed scatter in the $\mathrm{H}_{2} \mathrm{O}$ concentrations is reflected in the variable $\mathrm{H}_{2} \mathrm{O}$ / $\mathrm{K}_{2} \mathrm{O}$ ratios that range from 0.24 to 1.49 , in contrast to the nearly constant $\mathrm{P}_{2} \mathrm{O}_{5} / \mathrm{K}_{2} \mathrm{O}$ ratios (fig. 3). We have subdivided the samples into three arbitrary groups based on their $\mathrm{H}_{2} \mathrm{O} / \mathrm{K}_{2} \mathrm{O}$ ratios: (1) low $-\mathrm{H}_{2} \mathrm{O} / \mathrm{K}_{2} \mathrm{O}$ samples having $\mathrm{H}_{2} \mathrm{O} / \mathrm{K}_{2} \mathrm{O}$ ratios less than or equal 0.7 ; (2) moderate- $\mathrm{H}_{2} \mathrm{O} / \mathrm{K}_{2} \mathrm{O}$ samples having $\mathrm{H}_{2} \mathrm{O} / \mathrm{K}_{2} \mathrm{O}$ ratios ranging from 0.7 to 1.0 ; and (3) high- $\mathrm{H}_{2} \mathrm{O} / \mathrm{K}_{2} \mathrm{O}$ samples having $\mathrm{H}_{2} \mathrm{O} / \mathrm{K}_{2} \mathrm{O}$ ratios $>1.0$. These three groups plot along roughly parallel trends on the $\mathrm{H}_{2} \mathrm{O}$ vs. $\mathrm{K}_{2} \mathrm{O}$ diagram (fig. $6 b$ ). $\mathrm{H}_{2} \mathrm{O}$ contents samples in each group are weakly negatively correlated with $\mathrm{MgO}$ content. Garcia et al. (1989) also found a rough negative correlation between $\mathrm{H}_{2} \mathrm{O}$ and $\mathrm{MgO}$ in other glasses from the Puna Ridge, but they did not observe $\mathrm{H}_{2} \mathrm{O}$ concentrations as low as those in our low $\mathrm{H}_{2} \mathrm{O} / \mathrm{K}_{2} \mathrm{O}$ group.

Dissolved S. - The S contents of the Puna Ridge glasses range from 220 to $1440 \mathrm{ppm}$ by weight. The values for the off-rift samples (70-240 ppm by weight) are similar to those reported for fountain spatter from Kilauea (Swanson and Fabbi 1973; Gerlach and Graeber 1985) and support the idea that these samples were subaerially degassed. Flow $1742 \mathrm{a}$ has a $\mathrm{S}$ content $(220 \mathrm{ppm})$ similar to those of the off-rift samples, even though it was dredged along the axis of the Puna Ridge at a depth of $1400 \mathrm{~m}$.

Though the use of a barite standard for microprobe analysis of $S$ results in $S$ values about $15 \%$ lower than when a sulfide standard is used [e.g., compare the MORB trend presented in fig. 7 with that of Mathez (1976)], our values still tend to be higher (from $8 \%$ lower to $30 \%$ higher) than those in samples from the same flow units analyzed using $\mathrm{X}$-ray fluorescence spectrometry (Moore and Fabbi 1971) on nine whole-rock samples and corrected for the mass fraction of phenocrysts, or using vacuum fusion/mass spectrometry (Killingley and Muenow 1975; 

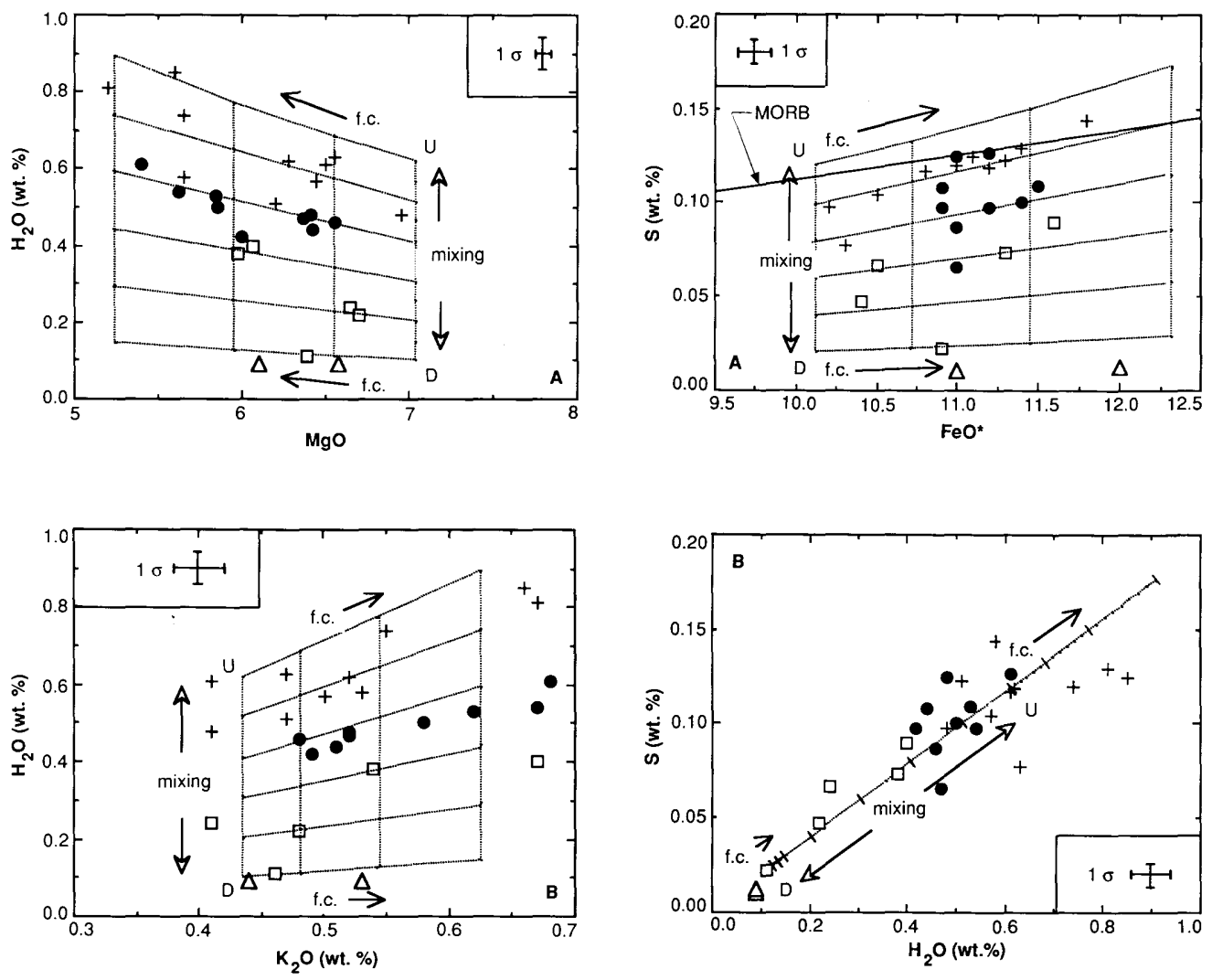

Fig. 6.-(a) Dissolved $\mathrm{H}_{2} \mathrm{O}$ vs. MgO. (b) Dissolved $\mathrm{H}_{2} \mathrm{O}$ vs. $\mathrm{K}_{2} \mathrm{O}$. Open squares: low- $\mathrm{H}_{2} \mathrm{O} / \mathrm{K}_{2} \mathrm{O}$ samples with $\mathrm{H}_{2} \mathrm{O} / \mathrm{K}_{2} \mathrm{O}$ ratios $\leq 0.7$; Filled circles: moderate $-\mathrm{H}_{2} \mathrm{O} / \mathrm{K}_{2} \mathrm{O}$ samples with $\mathrm{K}_{2} \mathrm{O} / \mathrm{H}_{2} \mathrm{O}$ ratios between 0.7 and 1.0 ; Crosses: high $-\mathrm{H}_{2} \mathrm{O} / \mathrm{K}_{2} \mathrm{O}$ samples with $\mathrm{H}_{2} \mathrm{O} / \mathrm{K}_{2} \mathrm{O}>1.0$; Open triangles: off-rift (subaerially degassed) samples; U: Undegassed end member; D: Degassed end member; Trends resulting from mixing of degassed and undegassed magmas calculated using mixing equations in Langmuir et al. (1978) and shown by open-ended arrows. Trends resulting from fractional crystallization (f.c.) shown by solid arrows. Extent of fractional crystallization is constrained by major element models. Grid lines shown at $20 \%$ intervals for mixing proportions and $10 \%$ intervals for fractional crystallization.

Muenow et al. 1979) on 13 glass separates (fig. $4 b$ ). Our $\mathrm{S}$ concentrations are $18-50 \%$ higher than those measured using vacuum fusion/manometry on glass separates from seven samples (Harris 1981; Sakai et al. 1984) and using combustion/manometry on glass separates from four samples (Des Marais and Moore 1984) from the same flow units (fig. $4 b$ ). Some of the discrepancies between our measurements of $S$ in the glass and previous

FIG. 7.- (a) Dissolved S vs. FeO. MORB S trend line is based on microprobe analysis of glasses from Juan de Fuca and Gorda Ridges (D. A. Clague unpub. data) obtained using the same S standardization as the data in this study and are about 15\% lower than those of Mathez (1976), obtained using a sulfide standard for $\mathrm{S}$. The wide range of $\mathrm{S}$ concentrations at a given $\mathrm{FeO}^{*}$ content in Puna Ridge glasses contrasts with the narrow range observed in MORB glasses. (b) Dissolved $\mathrm{S}$ vs. $\mathrm{H}_{2} \mathrm{O}$. Classification of samples and trends resulting from mixing of degassed and undegassed magmas and fractional crystallization are the same as in figure 6.

analyses of $S$ in bulk samples may be related to the type of sample analyzed; for example, in addition to the glassy rim, the whole-rock samples analyzed by Moore and Fabbi (1971) may have included unknown amounts of the crystalline interior that may have lost some sulfur upon crystallization (Moore and Fabbi 1971). Other discrepancies could reflect analytical techniques; for example, our S concentrations may be systematically high (though the discrepancy would be even worse if a sulfide standard had been used), or perhaps $S$ is not completely released during 
stepped-heating fusion and combusion techniques. Though the interlaboratory comparison suggests that the accuracy of sulfur determinations is poorly known, the $\mathrm{S}$ analyses presented in this study are precise and can be directly compared to the IR analyses of $\mathrm{H}_{2} \mathrm{O}$ and $\mathrm{CO}_{2}$ because both data sets were determined using microbeam techniques on glass.

There is no clear correlation between $\mathrm{S}$ concentration and depth (fig. $5 b$ ). As is observed for $\mathrm{H}_{2} \mathrm{O}$, the entire range of $\mathrm{S}$ contents occurs between 1400 and $1600 \mathrm{~m}$ water depth.

$S$ concentrations are plotted against $\mathrm{FeO}^{*}$ (total iron reported as $\mathrm{FeO}$ ) in figure $7 a$ with the correlation observed in MORB glasses (based on analyses obtained using the same microprobe standards and procedures used here; Clague unpub. data). $S$ concentrations in Kilauean glasses are lower than MORB glasses at the same $\mathrm{FeO}^{*}$ concentration. The samples with the highest $S$ contents at a given $\mathrm{FeO}^{*}$ content are within error of the line defined by MORB glasses, which has been interpreted as defining sulfide-saturated liquid compositions (Mathez 1976). Note that the MORB $\mathrm{FeO}^{*}-\mathrm{S}$ trend shown on figure $7 a$ is about $15 \%$ lower than that of Mathez (1976), presumably due to differences in microprobe standardization for $\mathrm{S}$. Most of the samples with highest $S$ contents belong to our high $\mathrm{H}_{2} \mathrm{O} / \mathrm{K}_{2} \mathrm{O}$ group. We consider the large range in $\mathrm{S}$ contents in Kilauean glasses, which contrasts with what has been observed in MORB glasses, to be a significant feature of our data set.

There is a positive correlation between $\mathrm{H}_{2} \mathrm{O}$ and $\mathrm{S}$ (fig. $7 b$ ), defined mainly by the five members of the low- $\mathrm{H}_{2} \mathrm{O} / \mathrm{K}_{2} \mathrm{O}$ group. The range of $\mathrm{S}$ concentrations reported for other submarine glasses from Kilauea (Garcia et al. 1989) is similar to that spanned by our high- and moderate- $\mathrm{H}_{2} \mathrm{O} / \mathrm{K}_{2} \mathrm{O}$ samples.

Dissolved $\mathrm{CO}_{2}$.-Dissolved $\mathrm{CO}_{2}$ concentrations in the along-rift glasses range from below detection limits to $280 \mathrm{ppm}$. The only forms of dissolved $\mathrm{CO}_{2}$ detected in these samples are carbonate ion complexes. No detectable $\mathrm{CO}_{2}(<10 \mathrm{ppm})$ was found in the offrift (subaerially degassed) glasses.

$\mathrm{CO}_{2}$ contents of some of the same flows analyzed by us have been analyzed by other workers (Muenow et al. 1979; Harris 1981; Des Marais and Moore 1984; Mattey et al.
1984). Although a detailed comparison shows considerable scatter (fig. 4c), our measurements are similar to those of Harris (1981), Des Marais and Moore (1984), and Mattey et al. (1984), but significantly lower than those of Muenow et al. (1979). Such discrepancies in interlaboratory comparisons of $\mathrm{CO}_{2}$ contents of basaltic glasses are well documented but poorly understood (see Des Marais 1986; Fine and Stolper 1986; Craig 1987; Exley et al. 1987; Stolper and Holloway 1988; Dixon et al. 1988).

$\mathrm{CO}_{2}$ concentrations are plotted vs. depth in figure $5 c$, along with the experimentally determined solubility curve of $\mathrm{CO}_{2}$ in basalt at $1200^{\circ} \mathrm{C}$ for pressures up to $1.5 \mathrm{kbar}$ (Stolper and Holloway 1988). Though scattered, the dissolved $\mathrm{CO}_{2}$ contents show a positive correlation with depth. The slope of a linear regression line through the data and forced through zero yields a slope of $42 \pm 2$ $(1 \sigma) \mathrm{ppm} / \mathrm{km}$. This value is within error of the slope of $38 \pm 2(1 \sigma) \mathrm{ppm} / \mathrm{km}$ for the solubility data of Stolper and Holloway (1988) but lower than a slope of $59 \mathrm{ppm} / \mathrm{km}$ for the apparent solubility curve of Harris (1981). Several samples, however, deviate significantly either positively or negatively from the solubility curve. Dissolved $\mathrm{CO}_{2}$ contents do not correlate with major or minor element concentrations, or with water contents.

Sample D4, dredged from near the rift zone at a depth of $5470 \mathrm{~m}$, contains about $280 \mathrm{ppm}$ $\mathrm{CO}_{2}$, approximately $70 \mathrm{ppm} \mathrm{CO}_{2}$ in excess of the solubility at this depth. Sample D5 is from a voluminous lava flow of uncertain eruption depth located at the base of the rift and contains about $260 \mathrm{ppm} \mathrm{CO}_{2}$. Based on the similar $\mathrm{CO}_{2}$ contents of these two samples, we suggest that the lava flows sampled by $\mathrm{D} 4$ and D5 erupted at about the same depth; it is possible, and consistent with the distribution of the lava flow (see fig. 1), that D5 erupted in the vicinity of sample D4 and, channelled by the moat, flowed laterally along the base of the rift to its present location.

Our $\mathrm{CO}_{2}$ data are not in agreement with those of Garcia et al. (1989). Their reported $\mathrm{CO}_{2}$ concentrations for submarine Kilauean glasses range from 350 to $1350 \mathrm{ppm}$ in excess of the solubility at the depth of eruption, whereas our values are supersaturated by no more than $70 \mathrm{ppm}$. Their $\mathrm{CO}_{2}$ concentrations were measured on bulk samples using vac- 
uum fusion/mass spectrometry, a technique that commonly gives $\mathrm{CO}_{2}$ values much higher than FTIR analyses on the same samples. We emphasize that our analyses are determined using the same technique as those constraining the solubility curve of Stolper and Holloway (1988) and measure only $\mathrm{CO}_{2}$ dissolved in the glass.

Glass Inclusions. - Analyses of glass inclusions in olivine, plagioclase, clinopyroxene, and orthopyroxene are presented in Clague et al. (1991). Based on major and minor element compositions of these inclusions (Clague et al. 1991), they have crystallized a small $(<20 \%)$ but variable percentage of their volume onto the walls of the host phase.

The only volatile element we have analyzed in the inclusions is $\mathrm{S}$, which was determined by electron microprobe as in the host glasses. The $\mathrm{S}$ contents of glass inclusions range from $220-1380 \mathrm{ppm}$ in 45 analyzed olivine crystals, from $750-1560 \mathrm{ppm}$ in four analyzed plagioclase crystals, from 970-1980 in four analyzed clinopyroxene crystals, and is $1400 \mathrm{ppm}$ in a single orthopyroxene crystal. Several small gabbroic xenoliths also contain glass inclusions in olivine (six analyses ranging from 370-1630 ppm S), clinopyroxene (two analyses of 680 and $1300 \mathrm{ppm} \mathrm{S}$ ), and plagioclase (one analysis of $750 \mathrm{ppm} \mathrm{S}$ ). Even though the $S$ contents of all these glass inclusions are presumably higher than the $S$ content of the melt that was originally trapped in the crystals (because of the effects of crystallization on the inclusion walls) the facts that some glass inclusions have $\mathrm{S}$ contents as low as the lowest value observed in the rind glasses and that enrichments due to crystallization on inclusion walls are $\leq 20 \%$ suggest to us that the host phenocrysts grew from magmas having a wide range of volatile contents. We note that many of the glass inclusion compositions are above the inferred sulfide saturation line in FeO-S (fig. 8b), and that no sulfide phases have been observed in these inclusions, suggesting that sulfide nucleation was inhibited within the inclusions during post-entrapment crystallization of the host phase.

\section{INTERPRETATIONS}

Major Element Chemistry.-Wright and Fiske (1971) demonstrated that lavas from
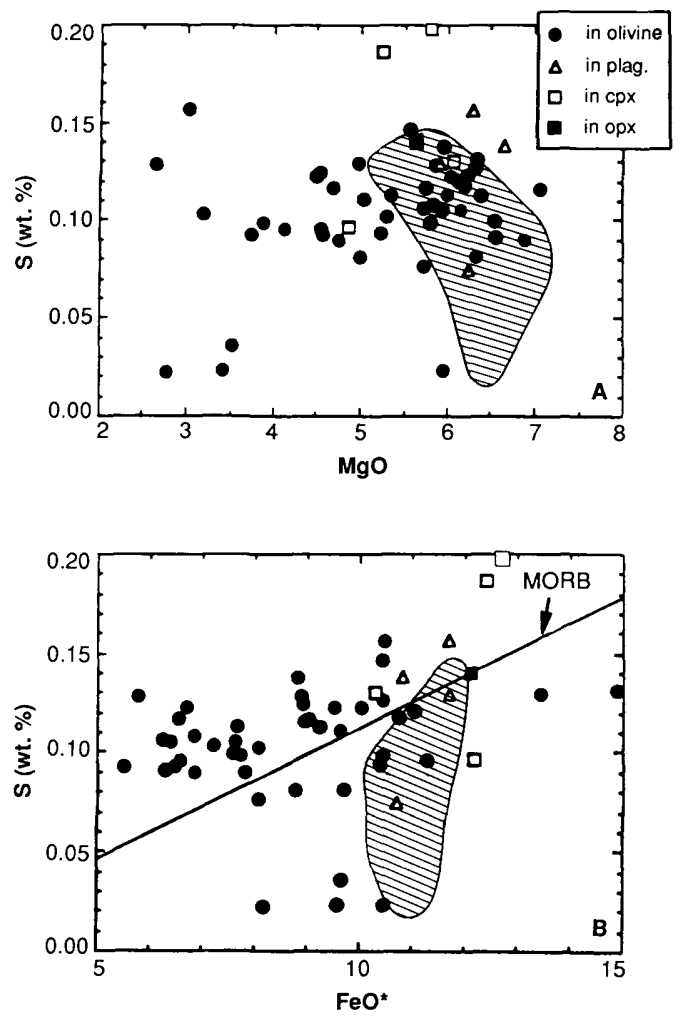

FIG. - 8.-Dissolved S contents in glass inclusions. Cross-hatched fields surround data from glassy rinds. (a) $\mathrm{S}$ vs. $\mathrm{MgO}$; $(b) \mathrm{S}$ vs. $\mathrm{FeO}^{*}$.

Kilauea with $\mathrm{MgO}>6.8$ wt \% plot along olivine-control lines. Puna Ridge glasses generally have lower $\mathrm{MgO}$ contents than the lower limit for olivine controlled lavas from Kilauea and define trends distinct from olivine-control lines, but similar or parallel to those for strongly fractionated lavas from Kilauea (Wright and Fiske 1971). In particular, the trends of decreasing $\mathrm{CaO}$ and $\mathrm{Al}_{2} \mathrm{O}_{3}$ with decreasing $\mathrm{MgO}$ result from crystallization of clinopyroxene and plagioclase in addition to olivine, as demonstrated by experimental studies of Kilauean lavas (Thompson and Tilley 1969; Helz and Thornber 1987).

The trends in the major element data are generally consistent with fractional crystallization of up to $30 \%$ olivine, plagioclase, and clinopyroxene in proportions of 1:5.2:4.9 from a parental magma containing $7.0 \mathrm{wt} \%$ $\mathrm{MgO}$ (fig. 2). Although this simple fractionation model successfully reproduces most of the observed trends in major element chemis- 
try, it cannot account for the low $\mathrm{FeO}^{*}$ contents, or the high $\mathrm{P}_{2} \mathrm{O}_{5}$ and $\mathrm{K}_{2} \mathrm{O}$ contents, of the most fractionated samples. Chemical evidence for the fractionation of latecrystallizing phases not on the liquidi of erupted lavas (e.g., oxide crystallization to account for the low $\mathrm{FeO}$ contents), and greater increases of incompatible elements with fractionation than can be generated by simple fractional crystallization, are characteristics common to many suites of volcanic rocks and may be caused by mixing of residual melts from the crystallizing margins of the magma chamber with well-mixed convecting magma in the interior (Langmuir 1989) or by periodic replenishment of magma bodies that are fractionating and serving as sources of erupted lavas (O'Hara 1977; O'Hara and Mathews 1981). Data on mineral assemblages and their compositions support an explanation of these deviations from simple liquid lines of descent that invokes an important role for magma mixing (Clague et al. 1991). Moreover, as we show below, magma mixing appears to play a critical role in generating the range of volatile contents observed in submarine lavas. Some of the observed deviations in incompatible element concentrations from the simple liquid line of descent may also be related to variable degrees of partial melting or to source region heterogeneity (Wright 1971; Hofmann et al. 1984; Garcia et al. 1989; Clague et al. 1991).

Magma Ascent Rate and $\mathrm{CO}_{2}$ Supersaturation.-The $\mathrm{CO}_{2}$ contents of the Puna Ridge glasses, which are approximately saturated with $\mathrm{CO}_{2}$-rich vapor at their depth of eruption, differ from those for glasses from the East Pacific Rise and Juan de Fuca Ridge (Fine and Stolper 1986; Dixon et al. 1988), where many of the glasses are significantly supersaturated with respect to $\mathrm{CO}_{2}$-rich vapor at their eruption depth. The $\mathrm{CO}_{2}$-supersaturated nature of the mid-ocean ridge lavas has been attributed to incomplete degassing during rapid ascent and eruption. The simplest explanation for the correspondence between the dissolved $\mathrm{CO}_{2}$ contents of most glasses from the Puna Ridge and the solubility curve is that magmas erupted along the Puna Ridge rose and erupted slowly enough to allow nearly complete exsolution of a $\mathrm{CO}_{2}$-rich vapor prior to quenching. If this is the case, it implies that magmas along the
Puna Ridge typically take more time to travel from a magma reservoir to their final site of quenching on the seafloor than those along the East Pacific Rise and Juan de Fuca Ridge. The predominance of pillow lavas along the Puna Ridge (Lonsdale 1989) is consistent with low effusion rates (Ballard et al. 1979; Holcomb and Clague 1983). The only samples from the Puna Ridge that plot significantly above the solubility curve in figure $5 c$ are those from the deepest dredges. Incomplete degassing of these samples would be consistent with the observed increase in the proportion of sheet flows, which are thought to erupt at higher effusion rates than pillows (Ballard et al. 1979; Holcomb and Clague 1983), with depth along the rift (Lonsdale 1989).

$\mathrm{H}_{2} \mathrm{O}$ and $\mathrm{S}$ Contents. $-\mathrm{H}_{2} \mathrm{O}$ behaves as an incompatible element during partial melting and fractional crystallization of anhydrous phases; therefore, if these were the only processes affecting the magma composition, $\mathrm{H}_{2} \mathrm{O}$ would correlate approximately linearly with other incompatible elements (such as $\mathrm{K}_{2} \mathrm{O}$ ) as has been found in MORB (e.g., Moore 1970; Michael and Chase 1987; Dixon et al. 1988). The wide range of $\mathrm{H}_{2} \mathrm{O}$ and $\mathrm{S}$ contents at the same $\mathrm{MgO}, \mathrm{FeO}$, and $\mathrm{K}_{2} \mathrm{O}$ contents (figs. $6 a, 6 b$, and $7 a$ ) demonstrates that processes other than, or in addition to, crystal-liquid fractionation of anhydrous phases influences their concentrations. These samples are so low in $\mathrm{H}_{2} \mathrm{O}$ and $\mathrm{S}$ that it is unlikely they would be saturated with $\mathrm{H}$ - or S-rich crystalline phases, and as expected, such phases have not been observed in the lavas. Crystallization of hydrous or S-bearing phases, therefore, is also unlikely to have been as major factor in accounting for the observed variations in $\mathrm{H}_{2} \mathrm{O}$ and $\mathrm{S}$ contents. Moreover, the variations in $\mathrm{H}_{2} \mathrm{O} / \mathrm{K}_{2} \mathrm{O}$ and $\mathrm{S}$ / $\mathrm{K}_{2} \mathrm{O}$ ratios of up to a factor of 6 are not likely to be explained by source region heterogeneities because comparable variations are not observed in ratios of nonvolatile incompatible elements (e.g., $\mathrm{K}_{2} \mathrm{O} / \mathrm{P}_{2} \mathrm{O}_{5}$; see fig. 3).

Exsolution of a vapor phase is one possible mechanism for generating a range in concentrations of volatile components such as $\mathrm{H}_{2} \mathrm{O}$ and $\mathrm{S}$ while leaving those of nonvolatile incompatible elements unaffected. In order to assess whether degassing during submarine eruption can explain the observed range in 
$\mathrm{H}_{2} \mathrm{O}$ and $\mathrm{S}$, we need to compare the conditions under which substantial amounts of $\mathrm{H}_{2} \mathrm{O}$ and $\mathrm{S}$ degas from these magmas to those experienced on the seafloor. It is well known that $\mathrm{CO}_{2}$ exsolves from basaltic magma over a wide range of pressures and dominates the vapor phase at pressures greater than about 100 bar in low- $\mathrm{H}_{2} \mathrm{O}$ basalts such as MORB and ocean island tholeiites (Killingley and Muenow 1975; Moore et al. 1977; Delaney et al. 1978; Gerlach and Graeber 1985; Gerlach 1986). Existing solubility data for pure water in basalt (Hamilton et al. 1964) and studies of Kilauean lavas (Moore 1965; Killingley and Muenow 1975; Kyser and O'Neil 1984) indicate that degassing of $\mathrm{H}_{2} \mathrm{O}$ and $\mathrm{S}$ does not become significant in these melts until pressures lower than about 100 bars are reached (corresponding to water depths shallower than $1000 \mathrm{~m}$ or magma column heights less than about $400 \mathrm{~m}$ ). The fact that the samples from shallower than $1000 \mathrm{~m}$ depth have $\mathrm{H}_{2} \mathrm{O}$ and $\mathrm{CO}_{2}$ concentrations near their solubilities at pressures corresponding to their depths of eruption (fig. $5 a$ and $c$ ) is consistent with saturation with respect to a vapor phase containing significant concentrations of both $\mathrm{CO}_{2}$ and $\mathrm{H}_{2} \mathrm{O}$ during submarine eruptions at these depths. Partial degassing on submarine eruption might thus account for depletions in $\mathrm{H}_{2} \mathrm{O}$ and $\mathrm{S}$ in Puna Ridge glasses erupted shallower than $1000 \mathrm{~m}$, but it cannot be a significant factor in explaining the range of $\mathrm{H}_{2} \mathrm{O}$ and $S$ contents of samples erupted deeper than $1000 \mathrm{~m}$.

Another important aspect of the data for samples erupted deeper than $1000 \mathrm{~m}$ is that glasses low in $\mathrm{H}_{2} \mathrm{O}$ and $\mathrm{S}$ are not also systematically low in $\mathrm{CO}_{2}$ (fig. $5 \mathrm{c}$ ). Thus, the observed range of $\mathrm{H}_{2} \mathrm{O}$ and $\mathrm{S}$ in the $>1000 \mathrm{~m}$ samples cannot be a relic of a single episode of low pressure degassing at some point in their evolution prior to their eruption on the submarine Puna Ridge. If this were the case, the $\mathrm{CO}_{2}$ contents should be essentially zero, because at pressures low enough to degas substantial quantities of $\mathrm{H}_{2} \mathrm{O}$ and $\mathrm{S}$, nearly all of the $\mathrm{CO}_{2}$ would also exsolve from the melt (Gerlach 1986). The correspondence of most of the $\mathrm{CO}_{2}$ data to the solubility curve (fig. 5c) is strong evidence that these samples last degassed under submarine conditions near their depths of eruption on the Puna Ridge, and that their pre-eruptive $\mathrm{CO}_{2}$ con- tents were even higher than their current values. These data thus argue strongly that the range of $\mathrm{H}_{2} \mathrm{O}$ and $\mathrm{S}$ contents observed in samples deeper than $1000 \mathrm{~m}$ are not the result of a single episode of low pressure degassing at some point in their history. Note that the off-rift samples do not contain detectable $\mathrm{CO}_{2}$ consistent with a single stage of subaerial degassing in their evolution.

Our preferred explanation for the observed depletions in $\mathrm{H}_{2} \mathrm{O}$ and $\mathrm{S}$ that are uncorrelated with nonvolatile incompatible elements is that the lavas we have studied are samples of mixed magmas, one component of which was degassed (i.e., either by actual subaerial eruption or in a shallow magma chamber in which total pressure was less than lithostatic, perhaps by connection through cracks to the surface) and one that was not. Thus, although these magmas erupted in submarine environments, they have inherited to varying degrees the characteristic $\mathrm{H}_{2} \mathrm{O}$ and $\mathrm{S}$ depletions of lavas degassed at low total pressure. Our model is illustrated schematically in figure 9. In the following sections, we discuss some of the consequences of our model in quantitative terms.

Quantitative Modeling.-We have developed a simple quantitative model that describes the mixing hypothesis presented in the preceding paragraph. We assume that each glass composition can be generated by the following sequence of processes: (1) mixing of undegassed and degassed liquids; (2) fractional crystallization of olivine, clinopyroxene, and plagioclase from this mixture to generate a residual liquid; and (3) further degassing during eruption on the sea floor (principally of $\mathrm{CO}_{2}$ for eruption depths $>1000 \mathrm{~m}$; $\mathrm{H}_{2} \mathrm{O}$ and probably $\mathrm{S}$, in adition to $\mathrm{CO}_{2}$ for eruption depths $<1000 \mathrm{~m}$ ).

For both degassed and undegassed end members, we chose a liquid with a major element composition (shown as " $P$ "' in fig. 2; composition listed in caption to fig. 2) similar to the most primitive analyzed glass $(\mathrm{MgO}$ $\sim 7.0 \mathrm{wt} \%$ ) from the Puna Ridge because glasses with high and low $\mathrm{H}_{2} \mathrm{O}$ contents are found at this primitive end of our sample distribution (fig. 6a). To account for all of our $\mathrm{H}_{2} \mathrm{O}$ data, the $\mathrm{H}_{2} \mathrm{O}$ content of the undegassed end member was chosen to be $0.62 \mathrm{wt} \%$ and the $\mathrm{H}_{2} \mathrm{O}$ content of the degassed end member was chosen to be $0.10 \mathrm{wt} \%$. The $\mathrm{S}$ content 


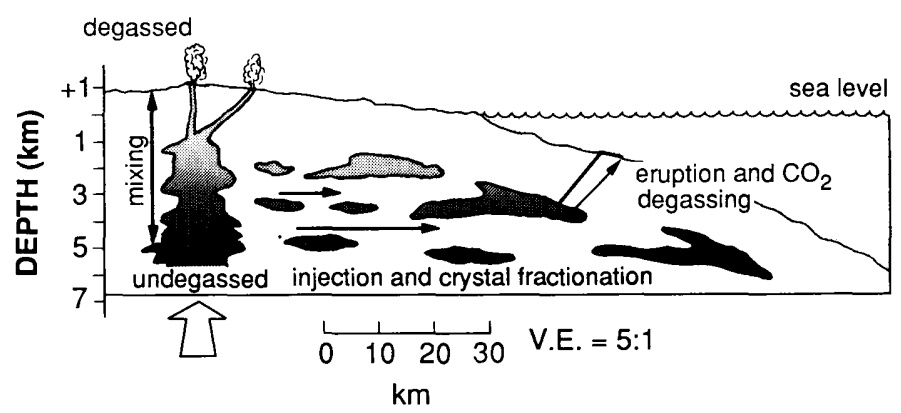

Fig. 9. - Schematic cross section of Kilauea Volcano (vertical exaggeration $5: 1$ ) illustrating our model for the degassing history of Puna Ridge tholeiites. Most magmas erupted along the Puna Ridge result from mixing of a relatively volatile-rich, undegassed component with magmas that experienced low pressure (perhaps subaerial) degassing during which substantial $\mathrm{H}_{2} \mathrm{O}, \mathrm{S}$, and $\mathrm{CO}_{2}$ were lost. The gradient in stippling density from light to dark represents a decrease in the proportion of degassed component with depth in the summit magma reservoir. Olivine, clinopyroxene, and plagioclase are removed from this mixture to generate a residual liquid. Further degassing, principally of $\mathrm{CO}_{2}$ for samples erupted deeper than $1000 \mathrm{~m}$, occurs during eruption on the seafloor.

of the undegassed end member was chosen to be $1200 \mathrm{ppm}$ and that of the degassed end member was chosen to be $200 \mathrm{ppm}$; these values were chosen such that both end members have an $\mathrm{H}_{2} \mathrm{O} / \mathrm{S}$ ratio close to the average of 5.1 (see fig. $7 b$ ). The $\mathrm{CO}_{2}$ content of the undegassed end member was chosen to be $480 \mathrm{ppm}$, which is the minimum value required to account for the highest $\mathrm{CO}_{2}$ content glasses we have analyzed. The degassed end member is assumed to have no $\mathrm{CO}_{2}$. The concentrations of $\mathrm{H}_{2} \mathrm{O}, \mathrm{S}$, and $\mathrm{CO}_{2}$ in the degassed end merhber are close to those measured in the off-rift glasses (table 4).

The proportions of the two end members and the amount of subsequent fractional crystallization for each sample are listed in table 5. Because the $\mathrm{CaO}$ data show the least scatter with respect to the calculated fractional crystallization trend as discussed above, the amount of fractional crystallization needed to generate the major element composition of the each glass from a parent magma " $P$ " was estimated using its $\mathrm{CaO}$ content. The $\mathrm{H}_{2} \mathrm{O}$ concentration of the reconstructed parental magma composition for each glass was then calculated by correcting for this amount of fractional crystallization. This $\mathrm{H}_{2} \mathrm{O}$ content was then used as the basis for calculating the proportions of degassed and undegassed end members in the parental magma.

Several aspects of this quantitative modeling require clarification. First, the choices of degassed and undegassed end members are not unique. For example, the undegassed end member could have higher $\mathrm{H}_{2} \mathrm{O}, \mathrm{S}$, and $\mathrm{CO}_{2}$ contents if all samples in our collection contain some of the degassed component. Also, the degassed end member could have lower or higher concentrations depending on the extent of degassing experienced by individual packets of magma. Second, nothing in our data set requires only two end members involved in the mixing process. For example, in one case the mixture could involve two unfractionated but variably degassed end members (this is the model we have chosen); in another, fractional crystallization of one or both end members could have preceded degassing of the volatile-depleted end member and mixing, after which more fractional crystallization and mixing could occur; in another, one or both end members could be more primitive (i.e., have higher $\mathrm{MgO}$ ) than the ones we have chosen. However, since the courses of fractional crystallization and degassing are little affected by each other on the scale we are considering, these additional permutations on the processes we are postulating would have little effect on the outcome of our modeling.

Our model accounts for the observed variations in, and correlations among, volatile and nonvolatile elements in Puna Ridge glasses. For example, our model defines, within $2 \sigma$ errors, a field that encompasses the $\mathrm{H}_{2} \mathrm{O}$, $\mathrm{MgO}$, and $\mathrm{K}_{2} \mathrm{O}$ data (fig. $6 a$ and $b$ ), although the most fractionated samples have $\mathrm{K}_{2} \mathrm{O}$ con- 
TABLE 5

Mdang and Fractional Crystalluzation Proportions

\begin{tabular}{lrrrr}
\hline Sample & \%Deg. & \%xtls & $\begin{array}{r}\text { model } \mathrm{CO}_{2} \\
\text { (ppm) }\end{array}$ & $\begin{array}{c}\text { model S } \\
\text { (wt \%) }\end{array}$ \\
& & & & \\
\hline 1684 & 34.2 & 6.0 & 336 & .091 \\
1717 & 59.2 & 18.0 & 239 & .074 \\
D45a & 34.0 & 11.4 & 358 & .097 \\
D45b & 54.6 & 20.0 & 272 & .082 \\
1685 & 55.0 & 16.4 & 258 & .078 \\
$1742 \mathrm{a}$ & 100.0 & 16.4 & 0 & .024 \\
$1742 \mathrm{~b}$ & 34.2 & 8.0 & 343 & .093 \\
SU56a & 79.6 & 6.5 & 105 & .043 \\
SU56b & 38.1 & 25.5 & 399 & .110 \\
1689 & 11.0 & 30.4 & 613 & .157 \\
1688 & 35.8 & 14.9 & 362 & .099 \\
D43a & 28.8 & 2.0 & 349 & .093 \\
D43b & 33.8 & 23.5 & 415 & .113 \\
D42a & 13.3 & 9.7 & 461 & .118 \\
D42b & 15.8 & 13.2 & 466 & .120 \\
1695 & 22.1 & 11.4 & 422 & .110 \\
$1697 b$ & 78.3 & 11.4 & 118 & .047 \\
1699 & 0 & 24.7 & 637 & .159 \\
1701 & 36.9 & 29.8 & 431 & .118 \\
1712 & 40.8 & 23.0 & 369 & .103 \\
1706 & 8.7 & 22.3 & 564 & .143 \\
1714 & 47.3 & 14.9 & 297 & .085 \\
D4-13 & 40.8 & 11.4 & 321 & .089 \\
D5-8 & 11.9 & 11.4 & 477 & .122 \\
& & & & \\
\hline NoTE & & & \\
\hline
\end{tabular}

NoTE--The amount of fractional crystallization (\%xtls) needed to generate the major element composition of each glass from a parent magma ("P" on fig. 2 containing 7.0 wt. \% $\mathrm{MgO}$ and 11.23 wt. \% $\mathrm{CaO}$ ) was estimated using its $\mathrm{CaO}$ content (see fig. 2). The proportions of degassed (\%Deg with 0.10 wt $\% \mathrm{H}_{2} \mathrm{O}, 200 \mathrm{ppm} \mathrm{S}$, and no $\left.\mathrm{CO}_{2}\right)$ and undegassed (100-\%Deg with 0.62 wt \% $\mathrm{H}_{2} \mathrm{O}, 1200 \mathrm{ppm} \mathrm{S}$, and $480 \mathrm{ppm} \mathrm{CO}_{2}$ ) end mem- bers were calculated by mass balance using the $\mathrm{H}_{2} \mathrm{O}$ content (corrected for \%xtls) of the reconstructed parent magma composition for each glass. Model $\mathrm{CO}_{2}$ and $S$ concentrations for each glass are our predicted values after mixing and fractional crystallization.

tents higher and $\mathrm{FeO}$ contents lower by more than $1 \sigma$ error than our model. As discussed above, these discrepancies could reflect the inadequacy of modeling complex magma chamber processes by simple fractional crystallization. At this point there is insufficient information properly to constrain the details of these complex processes, but because the solid-liquid partition coefficients of $\mathrm{H}_{2} \mathrm{O}, \mathrm{S}$, $\mathrm{K}_{2} \mathrm{O}$ and $\mathrm{P}_{2} \mathrm{O}_{5}$ are similar, these components will covary similarly whether simple fractional crystallization or more complex processes are incorporated into the modeling. In any case, the variability caused by fractional crystallization (or these more complex fractionation processes) is readily distinguishable from that produced by mixing of degassed and undegassed magmas.

The proportion of the degassed end member required to produce the moderate- and high- $\mathrm{H}_{2} \mathrm{O}$ group compositions is $<50 \%$. Note that although three of the five low- $\mathrm{H}_{2} \mathrm{O} / \mathrm{K}_{2} \mathrm{O}$ samples ( $>50 \%$ degassed end member) occur deeper than $1000 \mathrm{~m}$ (below the depth at which significant $\mathrm{H}_{2} \mathrm{O}$ and $\mathrm{S}$ are lost on submarine eruption), none of the samples in the low$\mathrm{H}_{2} \mathrm{O} / \mathrm{K}_{2} \mathrm{O}$ group occur deeper than $3000 \mathrm{~m}$ (the depth at which a change in slope of the rift axis occurs), suggesting that the proportions of degassed magma within magma reservoirs are greater at shallower levels.

Our model accounts well for the $S$ data (fig. $7 a$ and $b$ ), as expected, based on the roughly constant $\mathrm{H}_{2} \mathrm{O} / \mathrm{S}$ ratio of the samples. The positive correlation of $\mathrm{H}_{2} \mathrm{O}$ and $\mathrm{S}$ is produced by the colinear trends of degassing and fractional crystallization.

The behavior of $\mathrm{CO}_{2}$ predicted by our model is interesting in that, depending upon the proportions of the two end members and the depth of submarine eruption, the magmas may be either supersaturated or undersaturated with respect to $\mathrm{CO}_{2}$ on eruption. The following examples illustrate this point. Consider a batch of magma residing in a magma chamber at a depth of $4 \mathrm{~km}$ beneath the summit of Kilauea (lithostatic load about 1000 bars). A 50/50 mixture of degassed (no $\mathrm{CO}_{2}$ ) and undegassed (480 ppm $\mathrm{CO}_{2}$ ) magmas will have a $\mathrm{CO}_{2}$ content of about $240 \mathrm{ppm}$, undersaturated with respect to $\mathrm{CO}_{2}$ at this depth in the magma chamber. During lateral injection into the rift system and eruption, the pressure decreases to hydrostatic ( 300 bars), and the $\mathrm{CO}_{2}$ solubility decreases from 400 to 110 ppm. During eruption, therefore, the mixed magma will become supersaturated with respect to a vapor phase, and exsolution of $\mathrm{CO}_{2}$-rich vapor will occur. In this way, a magma can both be rich enough in $\mathrm{CO}_{2}$ to 
degas on submarine eruption, yet inherit the $\mathrm{H}_{2} \mathrm{O}$ and $\mathrm{S}$ depletion of shallow degassing (which, as discussed above, would in a single-stage process also strip the magma of all its $\mathrm{CO}_{2}$ ). However, if the mixing proportions were greater than about $80 \%$ of the degassed end member, the mixed magma would have $<110 \mathrm{ppm}$, and during eruption on the seafloor, $\mathrm{CO}_{2}$-rich vesicles would not form.

The behavior of $\mathrm{CO}_{2}$ in almost all of the Puna Ridge glasses is consistent with our proposed mixing model. Calculated mixing proportions listed in table 5 lead to the prediction that only one sample would be undersaturated with respect to $\mathrm{CO}_{2}$-rich vapor on eruption. This sample (1742a) contains no detectable $\mathrm{CO}_{2}$, is the only bubble-free sample shallower than $5000 \mathrm{~m}$, and as predicted, falls outside of errors below the solubility curve in figure $5 c$. The remaining samples are predicted to contain sufficient $\mathrm{CO}_{2}$ to become supersaturated with respect to $\mathrm{CO}_{2}$-rich vapor during eruption. The model does not predict, however, the absence of detectable $\mathrm{CO}_{2}$ in sample 1689 erupted at a depth of $1600 \mathrm{~m}$. We note that this sample is vesicular (4\% vesicles), highly fractionated (5.20 wt \% MgO), and contains an extremely high $\mathrm{H}_{2} \mathrm{O}$ content of $0.81 \mathrm{wt} \%$. Exsolution on eruption of vesicles rich in both $\mathrm{H}_{2} \mathrm{O}$ and $\mathrm{CO}_{2}$ could account at least qualitatively for the characteristics of this sample. It is interesting that the only sample from the Juan de Fuca Ridge that fell significantly below the experimentally determined $\mathrm{CO}_{2}$ solubility curve was also the most fractionated of the suite (Dixon et al. 1988), perhaps reflecting a similar effect. It is also possible that sample 1689 has undergone an episode of low pressure degassing following by migration down the rift system, as suggested by Des Marais and Moore (1984) for selected $\mathrm{CO}_{2}$-poor samples.

Isotopic Fractionation and Seawater Addition.-Kyser and O'Neil (1984) observed a positive correlation between $\delta \mathrm{D}$ $\left(-73\right.$ to $-33 \%$ o) and $\mathrm{H}_{2} \mathrm{O}$ contents $(0.24$ to $0.56 \mathrm{wt} \%$ ) in 10 glassy whole-rock samples from the Puna Ridge. They proposed that small amounts of seawater $(\delta \mathrm{D}=0 \%$ ) were added to unaltered magma $(\delta \mathrm{D}=-80 \%)$ at magmatic temperatures, resulting in increases in both $\delta \mathrm{D}$ and $\mathrm{H}_{2} \mathrm{O}$ contents. Seawater addition, however, would not readily explain the covariation of $\mathrm{H}_{2} \mathrm{O}$ and $\mathrm{S}$ observed in this study. A positive correlation between
$\mathrm{H}_{2} \mathrm{O}$ content and $\delta \mathrm{D}$ was not found, however, by Garcia et al. (1989) in glasses from four Kilauean tholeiites having a smaller range of $\delta \mathrm{D}$ values $(-61$ to $-74 \%$ ) and water contents $(0.44$ to $0.57 \mathrm{wt} \%)$ than the suite of samples studied by Kyser et al. (1984), nor is there any overlap between the two data sets (fig. 10).

Our model, with minor modifications, can account for the covariance of $\delta \mathrm{D}$ and $\mathrm{H}_{2} \mathrm{O}$ contents observed by Kyser and O'Neil (1984). We generated the degassed end member $\left(0.25 \mathrm{wt} \% \mathrm{H}_{2} \mathrm{O}\right.$ and $\delta \mathrm{D}$ of $-80 \%$ ) from the undegassed end member $\left(0.62\right.$ wt $\% \mathrm{H}_{2} \mathrm{O}$ and $\delta \mathrm{D}$ of $-35 \%$ ) by Rayleigh fractionation using a vapor/melt fractionation factor of 1.050. The fractionation factor needed to fit the data is at the high end of a wide range of values (1.010 to 1.050) suggested for high temperature degassing of basalt (Kyser and O'Neil 1984, Pineau and Javoy 1986) based on the $\delta \mathrm{D}$ values of coexisting glass and vapor in submarine basalts.

Figure 10 shows the range of $\mathrm{H}_{2} \mathrm{O}$ contents and $\delta \mathrm{D}$ values predicted by our model of mixing of degassed and undegassed magmas followed by fractional crystallization along with the data of Kyser and O'Neil (1984) and Garcia et al. (1989). Although there is considerable scatter in the observed $\delta \mathrm{D}$ values that cannot be rationalized by any simple model, our model of mixing and fractional crystallization explains the observed range in $\delta \mathrm{D}$ values and their correlation with $\mathrm{H}_{2} \mathrm{O}$ content reasonably well. The correspondence between our model and the data of Kyser and O'Neil (1984) is much poorer if we use a more degassed component for our degassed end member composition. If significant, this could suggest that the degassed end member may not typically be as fully degassed as the 0.10 wt $\% \mathrm{H}_{2} \mathrm{O}$ component used to generate Figures 6 and 7. Note that our reinterpretation of the data of Kyser and O'Neil (1984) implies that mantle source regions for Hawaiian tholeiites may have $\delta \mathrm{D}$ values as high as $\sim-30$ to $-40 \%$, significantly heavier than the value of $-80 \%$ assumed by other workers (Craig and Lupton 1976; Kyser and Q'Neil 1984) for the mantle source regions for Hawaii and MORB. In a study of another oceanic hotspot, Poreda et al. (1986) conclude that the mantle source regions for Iceland must have $\delta \mathrm{D}$ values heavier than MORB, in the range of -44 to $-74 \%$. Also, 


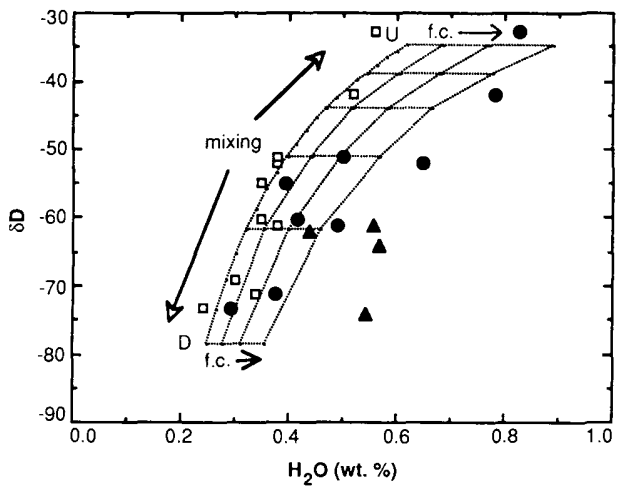

FIG. $10 .-\delta \mathrm{D}$ vs. dissolved $\mathrm{H}_{2} \mathrm{O}$. Open squares: Data of Kyser et al. (1984) on glassy whole-rock samples: Filled circles: $\mathrm{H}_{2} \mathrm{O}$ concentrations of Kyser and O'Neil (1984) corrected for mass fraction of phenocrysts; Filled triangles: Data of Garcia et al. (1989) on glass separates from Puna Ridge samples. Gridlines for mixing and fractional crystallization model are the same as in figure 6 . The isotopic composition of the degassed end member (D; $\mathrm{H}_{2} \mathrm{O}=0.25$ wt $\%, \delta \mathrm{D}=-80 \%$ ) was calculated from the undegassed end member $\left(\mathrm{U} ; \mathrm{H}_{2} \mathrm{O}=\right.$ $0.62 \mathrm{wt} \%, \delta \mathrm{D}=-35 \%$ ) using a Rayleigh fractionation model and a fractionation factor of 1.050 .

in a study of glasses from the East Pacific Rise, Chaussidon et al. (1989) document a positive correlation between $\delta \mathrm{D}$ and ${ }^{143} \mathrm{Nd} /$ ${ }^{144} \mathrm{Nd}$ ratios and use these data to suggest that the mantle source regions for these lavas have $\delta \mathrm{D}$ values ranging from -55 to $-84 \%$. These studies suggest that the mantle is heterogeneous with respect to hydrogen isotopes as well as with respect to radiogenic isotopes and concentrations of incompatible elements.

Volatile Content of Primary Magma.-We can estimate the volatile contents of Kilauean primary magma based on the composition of our hypothetical undegassed end member (0.62 wt \% $\left.\mathrm{H}_{2} \mathrm{O}, 1200 \mathrm{ppm} \mathrm{S}\right)$. Crystallization of about $25 \%$ olivine and minor amounts $(\sim 1 \%)$ of magnesiochromite from an average primary magma composition containing about $16 \% \mathrm{MgO}$ proposed by Clague et al. (1991) is required to generate the major element composition of the undegassed end member. Correcting for about $25 \%$ crystallization, we thus calculate that such a primary magma would contain about 0.47 wt $\% \mathrm{H}_{2} \mathrm{O}$ and 900 ppm S. These values must be considered minimum estimates, because we may not have sampled the undegassed end member composition (i.e., all samples may have some fraction of degassed magma). Also, the degree of partial melting, and consequently the concentrations of incompatible elements, may vary by as much as $\pm 20 \%$ from the average value for different batches of magma entering Kilauea (Clague et al. 1990), implying that the initial $\mathrm{H}_{2} \mathrm{O}$ content may range from about 0.38 to $0.56 \mathrm{wt} \%$ and the initial $\mathrm{S}$ content may range from 720 to $1080 \mathrm{ppm}$.

Several other approaches can be used to estimate the $S$ content of the primary magma. First, use of the highest $\mathrm{S} / \mathrm{K}_{2} \mathrm{O}$ ratio in the high-S glass inclusions in olivines $(0.238)$ and the $\mathrm{K}_{2} \mathrm{O}$ content of the average primary magma ( $0.39 \mathrm{wt} \%)$, yields an estimate of 930 ppm $S$ in the primary magma. Second, the highest $S$ content in glass inclusions in olivine from tephra erupted near the summit of $\mathrm{Ki}$ lauea (Clague unpub. data) is $1300 \mathrm{ppm}$ in a glass with 6.7 wt $\% \mathrm{MgO}$. Correction for about $35 \%$ fractional crystallization results in an estimate of $845 \mathrm{ppm} S$ in a primary melt composition.

Our estimated $\mathrm{H}_{2} \mathrm{O}$ content is higher than values of $0.32 \mathrm{wt} \%$ by Greenland et al. (1985) based on gas emission data and $0.30 \mathrm{wt} \%$ by Gerlach and Graeber (1985). Our estimate of the $\mathrm{S}$ content in the primary magma is nearly identical to that of Greenland et al. (1985) based on gas emission data but lower than a value of $1300 \mathrm{ppm}$ used by Gerlach and Graeber (1985) based on glass inclusion data of Harris and Anderson (1983) on glass inclusions with about $12 \% \mathrm{MgO}$.

Mechanisms for Generation and Recycling of Degassed Magma.-_Recycling of magma degassed at shallow levels in the crust may provide a possible mechanism for returning degassed magmas to the interior of the volcano for mixing with relatively undegassed magmas. Since the tops of the Kilauea summit magma chamber and rift zone reservoirs are on average about $2 \mathrm{~km}$ beneath the volcano surface (Fiske and Kinoshita 1969; Koyanagi et al. 1976; Ryan et al. 1981; Ryan 1988), corresonding to lithostatic pressures of about 500 to 560 bars (assuming crustal densities of 2.5 to $2.8 \mathrm{~g} / \mathrm{cm}^{3}$ ), significant amounts of $\mathrm{H}_{2} \mathrm{O}$ and $\mathrm{S}$ could not be simply lost from these magmas during residence in the magma reservoir, unless the pressure on the magma is much less than lithostatic. Considerable magmatic $\mathrm{CO}_{2}$ is lost during summit chamber degassing (Gerlach 1980; Gerlach and Graeber 1985; Greenland et al. 1985; Gerlach 
1986), and vigorous degassing at eruptive fissures with little or no lava appearing at the surface is commonly observed at Kilauea (Moore and Koyanagi 1969), impling the existence of open pathways from the surface to the magma and less than lithostatic pressures on the magma. The continuous emission of $\mathrm{SO}_{2}$ from high-temperature fumaroles during repose periods at Kilauea provides evidence that sulfur is able to degas even at times when magma does not reach the surface (Casadevall et al. 1980; Gerlach 1980; Harris and Anderson 1983; Greenland et al. 1985) and is consistent with the idea of less than lithostatic pressures in the summit chamber. Another possibility is that $\mathrm{CO}_{2}$-rich bubbles rising through the magma within the summit magma chamber (Vergniolle and Jaupart 1990) may progressively dehydrate the magma as has been hypothesized for the Bishop Tuff (Anderson et al. 1989). Thus, degassing of magma at depth in the summit magma chamber is one possible mechanism for generating the degassed component observed in submarine magmas erupted on the Puna Ridge.

Estimates for the amounts of $\mathrm{S}$ and $\mathrm{H}_{2} \mathrm{O}$ loss during summit chamber degassing are highly varied. Based on measured gas emission and magma supply rates, Greenland et al. (1985) estimate that magma residing in the summit magma reservoir degasses about $18 \%$ of its original S. Similar estimates for $\mathrm{H}_{2} \mathrm{O}$ cannot be made because of contributions of unknown amounts of meteoric water to the gas emission data, but the near constant $\mathrm{H}_{2} \mathrm{O}$ / $\mathrm{S}$ ratio shown in our data suggest that the proportion of $\mathrm{H}_{2} \mathrm{O}$ degassed could be close to that of S. Gerlach and Graeber (1985) estimate a higher value of $46 \%$ for the amount of original S lost during summit degassing, but they may have overestimated the $S$ concentration in the calculated chamber gas composition because of inaccuracies in analytical techniques used to measure $\mathrm{S}$ (as discussed above) in their parental (measured by microprobe) and stored (measured by XRF) magma compositions.

Recycling of degassed magma during sustained summit lava lake activity may also provide a mechanism for returning degassed magmas to the summit magma reservoir. Such phenomena have been well documented during historic eruptions of Kilauea. On a small scale, subaerial lava flows (e.g., the earliest phase of Puu O'o) were observed descending into pre-existing open cracks (Wolfe et al. 1987). On a larger scale, the 1919-1920 eruption at Mauna Iki on the southwest rift zone was fed by degassed lava drained from Halemaumau along shallow fissures (Jaggar 1947). The best documented example of lava lake backflow occurred during the Kilauea Iki summit eruption in 1959, for which Richter et al. (1970) observed backflow of lake lava down the vent during and following each of the 17 eruptive phases. Following phase 4 there was little net volume change in the lava lake, suggesting that a volume of lava comparable to that erupted reentered down the vent following each eruptive phase. Another example occurred on Feb. 7, 1960, when the still liquid core of the 1952 lava lake in Halemaumau drained away and resulted in the rapid collapse of the floor of Halemaumau (Richter et al. 1970, p. E70). This collapse and two smaller subsequent collapses in Halemaumau had a total volume of about 20 million $\mathrm{m}^{3}$, and this volume of degassed summit lake lava presumably drained into magma reservoirs beneath Kilauea's summit. Degassing of magma within the crust may also occur when magma moves to relatively shallow depths and then returns to the main reservoir; for example, the summit chamber is presently only $1 \mathrm{~km}$ below Halemaumau pit crater, and it is not unreasonable to suppose that magmas may reach within $0.5 \mathrm{~km}$ or less of the surface as they migrate through pathways in the summit region.

In contrast to the predominance of rift eruptions over the past $70 \mathrm{yr}$, the eruptive style of Kilauea during the 1800 s, and in fact over much of the last $10,000 \mathrm{yr}$ (including the times of eruption of most of the Puna Ridge lavas; Clague et al. 1991), was characterized by vigorous summit activity and formation of sustained summit lava lakes (Holcomb 1987). The predominance of such an eruptive style at the summit over the period in which the Puna Ridge samples erupted is consistent with the important role played by a degassed end member in our model for the generation of the Puna Ridge suite. Periods of sustained summit activity and subsequent catastrophic caldera collapse would provide opportunities for significant quantities of degassed magma to return to the magma reservoir and mix 
with relatively undegassed magma (perhaps new influxes of primitive magma), followed by lateral injection of the mixed magma into an adjacent rift system. Mixing may also be facilitated by convection in the reservoir initiated by caldera collapse.

Predictions for Other Volcanoes.-We predict that depletions in volatile elements similar to those observed in Puna Ridge glasses should be observed in samples from rift zones of oceanic volcanoes whose summits have breached the sea surface (e.g., Mauna Loa), but not in samples from completely submerged oceanic volcanoes (e.g., Loihi). The $\mathrm{H}_{2} \mathrm{O}$ contents of glasses from the submarine rift zone of Mauna Loa do indeed display a wide range at a given $\mathrm{MgO}$ content (Garcia et al. 1989), similar to that of $\mathrm{Ki}$ lauean glasses (fig. 11). In contrast and also as predicted, the $\mathrm{H}_{2} \mathrm{O}$ contents of tholeiitic glasses from the summit of Loihi are higher than those of most glasses from the Mauna Loa submarine rift (Garcia et al. 1989), comparable to our high $\mathrm{H}_{2} \mathrm{O} / \mathrm{K}_{2} \mathrm{O}$ samples (fig. 11). Similarly, $\mathrm{Cl}$ contents in tholeiitic glasses from Loihi are an order of magnitude higher than those in glasses from the submarine rift zones of Kilauea and Mauna Loa (Byers et al. 1985; Garcia et al. 1989). Byers et al. (1985) and Garcia et al. (1989) attributed these differences in $\mathrm{H}_{2} \mathrm{O}$ and $\mathrm{Cl}$ contents to differences in the volatile element contents of the mantle source regions of Loihi and Mauna Loa parent magmas. While source regions for different Hawaiian volcanoes may indeed differ, the difference between the volatile contents of tholeiitic glasses from Loihi and those from the submarine rifts of Kilauea and Mauna Loa can also be explained by invoking a role for low pressure (perhaps even subaerially) degassed magma in eruptions on the submarine portions of the rift zones of volcanoes whose summits have breached the ocean surface.

\section{CONCLUSIONS}

We have presented major and volatile element concentrations in basaltic glasses from the submarine portion of the east rift zone of Kilauea Volcano, Hawaii. Significant features of our data are: (1) $\mathrm{H}_{2} \mathrm{O} / \mathrm{K}_{2} \mathrm{O}$ ratios are highly variable, in contrast to the nearly constant ratios of nonvolatile incompatible elements (e.g., $\mathrm{H}_{2} \mathrm{O} / \mathrm{P}_{2} \mathrm{O}_{5}$ ); (2) $\mathrm{S}$ contents at a

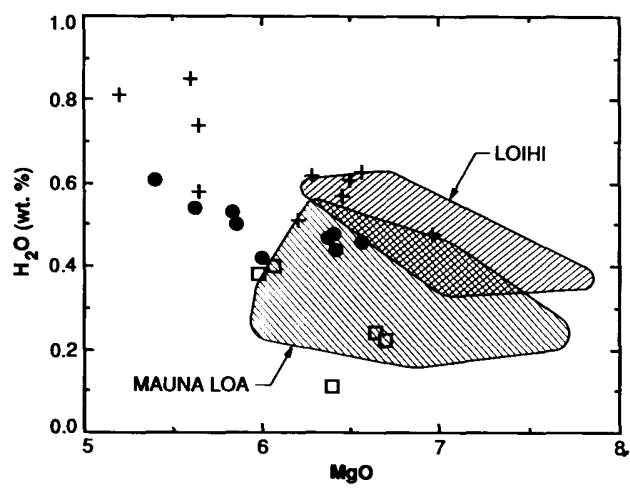

FIG. 11.-Comparison of $\mathrm{H}_{2} \mathrm{O}$ contents in lavas from Kilauea (symbols; this study), Mauna Loa and Loihi (cross-hatched fields; Garcia et al. 1989). Open squares: low $-\mathrm{H}_{2} \mathrm{O} / \mathrm{K}_{2} \mathrm{O}$ samples with $\mathrm{H}_{2} \mathrm{O}$ / $\mathrm{K}_{2} \mathrm{O}$ ratios $\leq 0.70$; Filled circles: moderate $-\mathrm{H}_{2} \mathrm{O}$ / $\mathrm{K}_{2} \mathrm{O}$ samples with $0.70<\mathrm{K}_{2} \mathrm{O} / \mathrm{H}_{2} \mathrm{O}<1.0$; Crosses: high- $\mathrm{H}_{2} \mathrm{O} / \mathrm{K}_{2} \mathrm{O}$ samples with $\mathrm{H}_{2} \mathrm{O} / \mathrm{K}_{2} \mathrm{O} \geq 1.0 . \mathrm{H}_{2} \mathrm{O}$ contents in samples from Loihi are higher than those from Mauna Loa, and are similar to the $\mathrm{H}_{2} \mathrm{O}$ concentrations in our high $\mathrm{H}_{2} \mathrm{O} / \mathrm{K}_{2} \mathrm{O}$ samples.

given $\mathrm{FeO}^{*}$ are highly variable and often much lower than required for sulfide saturation, in contrast to the simple trends observed in MORB glasses; (3) $\mathrm{S}$ contents in glass inclusions are highly variable, and (4) $\mathrm{CO}_{2}$ contents of most glasses agree within error with $\mathrm{CO}_{2}$ solubility at the pressure of eruption. These data cannot readily be explained by combinations of fractional crystallization, degassing during submarine eruption, seawater addition, or heterogeneities in the mantle source regions of the magmas.

Our data are consistent with generation of these submarine magmas by: (1) mixing of magmas depleted in $\mathrm{H}_{2} \mathrm{O}, \mathrm{S}$, and $\mathrm{CO}_{2}$ with relatively undegassed magmas (degassed to the extent that occurs on rise into the summit reservoir located at $>2-3 \mathrm{~km}$ depth beneath the summit of Kilauea); followed by (2) up to $30 \%$ fractional crystallization of olivine, clinopyroxene, and plagioclase in the proportions of 1:5.2:4.9 from the mixed magma to generate residual liquid; followed by ( 3 ) further degassing upon eruption on the seafloor, principally of $\mathrm{CO}_{2}$ for eruption depths $>1000$ $\mathrm{m}$ and of $\mathrm{CO}_{2}, \mathrm{H}_{2} \mathrm{O}$, and $\mathrm{S}<1000 \mathrm{~m}$. The degassed component can be generated in the upper levels of the summit magma chamber, if the summit magma reservoir experiences pressures much less than lithostatic, by a flux 
of $\mathrm{CO}_{2}$-rich bubbles rising through the magma, or during sustained summit eruptions and in lava lakes. Mixing of the degassed and undegassed components can occur as degassed magma is returned to the interior of the volcano, perhaps associated with drainbacks of lava lakes developed during sustained summit eruptions. The final phase of degassing during eruption on the seafloor occurs slowly enough to achieve melt/vapor equilibrium during exsolution of the typically $\mathrm{CO}_{2}$-rich vapor phase.

Based on the characteristics of the undegassed end member required by our mixing model, we predict that Kilauean primary magmas with $16.0 \% \mathrm{MgO}$ contain $\sim 0.47$ wt $\% \mathrm{H}_{2} \mathrm{O}$ and $\sim 900 \mathrm{ppm}$ S. We can also explain the observed positive correlation between $\mathrm{H}_{2} \mathrm{O}$ contents and $\delta \mathrm{D}$ values (Kyser and O'Neil 1984) if this component has a $\delta \mathrm{D}$ value of about -30 to $-40 \%$, which is much higher than previous estimates of the $\delta \mathrm{D}$ of primitive Hawaiian magmas. We also predict that submarine lavas from wholly submarine volcanoes (i.e., for which there is no opportunity to generate the degassed end member by low pressure degassing) will be enriched in volatiles relative to those from volcanoes whose summits have breached the sea surface. This is consistent with the observed volatile element enrichment in tholeiitic glasses from Loihi relative to submarine glasses from Kilauea and Mauna Loa (Buyers et al. 1985; Garcia et al. 1989).

\section{ACKNOWLEDGMENTS. - We thank Robert} Dixon for polishing the glass chips for IR analysis, Walt Friesen for the model data, and Steve Wessells and Walt Friesen for their assistance with the microprobe analyses. Jim Moore kindly allowed us access to his collection of Kilauea dredged lavas, without which the study would not have been possible. We thank Mike Baker for allowing us to use his fractional crystallization program. Jim Moore, Tom Wright, Terry Gerlach, and two anonymous reviewers provided thoughtful reviews of the manuscript. The research at Caltech was performed under NSF grant EAR-8811406. Caltech Division of Geological and Planetary Science Contribution Number 4832 .

\section{REFERENCES CITED}

Anderson, A. T.; Newman, S.; Williams, S. N.; Druitt, T. H.; Skirius, C.; and Stolper, E., $1989, \mathrm{H}_{2} \mathrm{O}, \mathrm{CO}_{2}, \mathrm{Cl}$, and gas in Plinian and ashflow Bishop rhyolite: Geology, v. 17, p. 221-225.

Ballard, R. D.; Holcomb, R. T.; and van ANDEL, T. J., 1979, The Galapagos Rift at $86^{\circ} \mathrm{W}, 2$ : volcanism, structure, and evolution of the rift valley: Jour. Geophys. Res., v. 84, p. 5407-5422.

Byers, C. D.; Garcia, M. O.; and Muenow, D. W., 1985, Volatiles in pillow rim glasses from Loihi and Kilauea Volcanoes, Hawaii: Geochim. Cosmochim. Acta, v. 49, p. 1887-1896.

Casadevall, T. J.; Malinconico, L. L.; LeGuern, F.; SAto, M.; Stolber, R.; McGee, K.; and HazLETT, R., 1980, Volcanic gas studies in Hawaii, 1878-1979 (abs.): EOS, v. 61, p. 67.

Chaussidon, M.; Sheppard, S. M. F.; and MICHARD, A., 1989, Hydrogen, sulfur, and neodymium isotope variations in the mantle beneath the EPR at $12^{\circ} 50^{\prime} \mathrm{N}$ : Epstein 70th Birthday Symposium, California Inst. Technology, p. 94.

Clague, D. A.; Holcomb, R. T.; Torresan, M.; and Ross, S., 1988, Shipboard report for Hawaii GLORIA ground-truth cruise F11-88-HW, 25 Oct.-7 Nov., 1988: U.S. Geol. Survey Open-file Rept. 89-109, 33 p.

- ; Moore, J. G.; Friesen, W. F.; and Dixon, J. E., 1990, The mineral chemistry and petrogenesis of submarine lavas from Kilauea's East Rift Zone, Hawaii: Jour. Petrol., in press.
Craig, H., 1987, Comment on "Carbon isotope systematics of a mantle hotspot: a comparison of Loihi Seamount and MORB glasses" by R. A. Exley, D. P. Mattey, D. A. Clague, and C. T. Pillinger: Earth Planet. Sci. Lett., v. 82, p. 384-386.

$\longrightarrow$, and Lupton, J. E., 1976, Primordial neon, helium, and hydrogen in oceanic basalts: Earth Planet. Sci. Lett., v. 31, p. 369-385.

Delaney, J. R.; Muenow, D. W.; and Graham, D. G., 1978, Abundance and distribution of water, carbon, and sulfur in the glassy rims of submarine pillow basalts: Geochim. Cosmochim. Acta, v. 42, p. 581-594.

Des Marais, D. J., 1986, Carbon abundance measurements in oceanic basalts: the need for a consensus: Earth Planet. Sci. Lett., v. 79, p. 21-26.

— isotopes in mid-oceanic basaltic glasses: Earth Planet. Sci. Lett., v. 69, p. 43-57.

Dixon, J. E.; Stolper, E.; and Delaney, J. R., 1988, Infrared spectroscopic measurements of $\mathrm{CO}_{2}$ and $\mathrm{H}_{2} \mathrm{O}$ in Juan de Fuca Ridge basaltic glasses: Earth Planet. Sci. Lett., v. 90, p. 87-104.

Exley, R. A.; Mattey, D. P.; and Pillinger, C. T., 1987, Low temperature carbon components in basaltic glasses - reply to comment by $\mathrm{H}$. Craig: Earth Planet. Sci. Lett., v. 82, p. 387-390.

Fine, G. J., and StolPer, E. M., 1986, Dissolved 
carbon dioxide in basaltic glasses: concentrations and speciation: Earth Planet. Sci. Lett., v. 76, p. 263-278.

Fiske, R. S., and Kinoshita, W. T., 1969, Inflation of Kilauea Volcano prior to its 1967-1968 eruption: Science, v. 165, p. 341-349.

Fornari, D. J.; Malahoff, A.; and Heezen, B. C., 1978, Volcanic structure of the crest of the Puna Ridge, Hawaii: geophysical implications of submarine volcanic terrain: Geol. Soc. America Bull., v. 89, p. 605-616.

Garcia, M. O.; Muenow, D.; Aggrey, K.; and O'NeIL, J., 1989, Major element, volatile and stable isotope geochemistry of Hawaiian submarine tholeiitic basalt: Jour. Geophys. Res., v. 94, p. 10,525-10,538.

Gerlach, T. M., 1980, Evaluation of volcanic gas analyses from Kilauea volcano: Jour. Volcanol. Geotherm. Res., v. 7, p. 295-317.

$\ldots$, 1986, Exsolution of $\mathrm{H}_{2} \mathrm{O}, \mathrm{CO}_{2}$, and $\mathrm{S}$ during eruptive episodes at Kilauea Volcano, Hawaii: Jour. Geophys. Res., v. 91, p. 12,17712,185 .

—, and Graeber, E. J., 1985, Volatile budget of Kilauea volcano: Nature, v. 313, p. 273-277.

Greenland, L. P.; Rose, W. I.; and Stokes, J. B., 1985, An estimate of gas emissions and magmatic gas content from Kilauea volcano: Geochim. Cosmochim. Acta, v. 49, p. 125-129.

Grove, T. L., and BAKER, M. B., 1984, Phase equilibrium controls on the tholeiitic versus calcalkaline differentiation trends: Jour. Geophys. Res., v. 89, p. 3253-3274.

- and BYraN, W. B., 1983, Fractionation of pyroxene-phyric MORB at low pressure: an experimental study: Contrib. Mineral. Petrol., v. 84, p. 293-309.

Hamilton, D. L.; Burnham, C. W.; and Osborn, E. F., 1964, The solubility of water and effects of oxygen fugacity and water content on crystallization in mafic magmas: Jour. Petrol., v. 5, p. 21-39.

HaRRIS, D. M., 1981, The concentration of $\mathrm{CO}_{2}$ in submarine tholeiitic basalts: Jour. Geology, v. 89 , p. 689-701.

tions, sources, and losses of $\mathrm{H}_{2} \mathrm{O}, \mathrm{CO}_{2}$ and $\mathrm{S}$ in Kilauean basalt: Geochim. Cosmochim. Acta, v. 47, p. 1139-1150.

Helz, R. T., and Thornber, C. R., 1987, Geothermometry of Kilauea Iki lava lake, Kilauea Volcano, Hawaii: Bull. Volcanology, v. 49, p. 651-658.

Hofmann, A. W.; Feigenson, M. D.; and Raczek, I., 1984, Case studies on the origin of basalt: III. Petrogenesis of the Mauna Ulu eruption, Kilauea, 1969-1971: Contrib. Mineral. Petrol., v. 88 , p. 24-35.

HоLсомв, R. T., 1987, Eruptive history and longterm behavior of Kilauea Volcano, in Volcanism in Hawaii, U.S. Geol. Survey Prof. Paper 1350, p. 261-350.

- , and Clague, D. A., 1983, Volcanic eruption patterns along submarine rift zones: Oceans 83 Proceedings, IEEE, New York, p. 787-790. ; Moore, J. G.; Lipman, P. W.; and Belder-
SON, R. H., 1988, Voluminous lava flows from Hawaiian volcanoes: Geology, v. 16, p. 400-404.

JAGGAR, T. A., 1947, Origin and development of craters: Geol. Soc. America Mem. 21, 508 p.

Jarosewich, E.; Nelen, J. A.; Norberg, J. A., 1979, Electron microprobe reference samples for mineral analyses: Smithsonian Contrib. Earth Sci. 20 , p. $68-72$.

Killingley, J. S., and Muenow, D. M., 1975, Volatiles from Hawaiian submarine basalts determined by dynamic high temperature mass spectrometry: Geochim. Cosmochim. Acta, v. 39, p. 1467-1473.

Koyanagi, R. Y.; Unger, J. D.; Endo, E. T.; and OKAmura, A. T., 1976, Shallow earthquakes associated with inflation episodes at the summit of Kilauea Volcano, Hawaii: Bull. Volcanology, v. 39, p. 621-631.

KySER, T. K., and O'NeIL, J. R., 1984, Hydrogen isotope systematics of submarine basalts: Geochim. Cosmochim. Acta, v. 48, p. 2123-2133.

LANGMUIR, C. H., 1989, Geochemical consequences of in situ crystallization: Nature, v. 340, p. 199-205.

—; Vocke, R. D., JR.; HANSON, G. N.; and HART, S. R., 1978, A general mixing equation with applications to Icelandic basalts: Earth Planet. Sci. Lett., v. 37, p. 380-392.

Lonsdale, P., 1989, A geomorphological reconnaissance of the submarine part of the East Rift Zone of Kilauea Volcano, Hawaii: Bull. Volcanology, v. 51, p. 123-144.

Mathez, E. A., 1976, Sulfur solubility and magmatic sulfides in submarine basalt glass: Jour. Geophys. Res., v. 81, p. 4269-4276.

Mattey, D. P.; CARR, R. H.; Wright, I. P.; and Pillinger, C. T., 1984, Carbon isotopes in submarine basalts: Earth Planet. Sci. Lett., v. 70, p. 196-206.

Michael, P. J., and Chase, R. L., 1987, The influence of primary magma composition, $\mathrm{H}_{2} \mathrm{O}$ and pressure on mid-ocean ridge basalt differentiation: Contrib. Mineral. Pet., v. 96, p. 245-263.

Moore, J. G., 1965, Petrology of deep-sea basalt near Hawaii: Am. Jour. Sci. v. 263, p. 40-52.

- _ 1970, Water content of basalt erupted on the ocean floor: Contrib. Mineral. Petrol., v. 28, p. 272-279.

-; Batchelder, J. N.; and Cunningham, C. G., 1977, $\mathrm{CO}_{2}$ filled vesicles in mid-ocean basalt: Jour. Volcanol. Geotherm. Res., v. 2, p. 309-327.

—, and Clague, D. A., 1987, Coastal lava flows from Mauna Loa and Hualalai volcanoes, Kona, Hawaii: Bull. Volcanology, v. 49, p. $752-764$.

$\longrightarrow$, and FABBI, B. P., 1971, An estimate of the juvenile sulfur content of basalt: Contrib. Mineral. Petrol., v. 33, p. 118-127.

, and Fiske, R. S., 1969, Volcanic substructure inferred from dredge samples and oceanbottom photographs, Hawaii: Geol. Soc. America Bull., v. 80, p. 1191-1203.

- , and Koyanagi, R. Y., 1969, The October 1963 eruption of Kilauea Volcano, Hawaii: U.S. Geol. Survey Prof. Paper 614-C,13 p. 
Muenow, D. W.; Graham, D. G.; Liu, N. W. K.; and Delaney, J. R., 1979, The abundance of volatiles in Hawaiian tholeiitic submarine basalts: Earth Planet. Sci. Lett., v. 42, p. 71-76.

Newman, S. N.; Stolper, E. M.; and Epstein, S., 1986, Measurement of water in rhyolitic glasses: calibration of an infrared spectroscopic technique: Am. Mineral., v. 71, p. 1527-1541.

O'Hara, M. J., 1977, Geochemical evolution during fractional crystallization of a periodically refilled magma chamber: Nature, v. 266, p. 503-507.

evolution in an advancing, periodically replenished, periodically tapped, continuously fractionated magma chamber: Jour. Geol. Soc. London, v. 138, p. 237-277.

Pineau, F., and Javoy, M., 1986, The volatile record of a "popping rock" from the Mid-Atlantic Ridge at $15^{\circ} \mathrm{N}$ : concentrations and isotopic compositions (abs.): Terra Cognita, v. 6, 191 p.

Poreda, R.; Schilling, J-G.; and Craig, H., 1986, Helium and hydrogen isotopes in ocean-ridge basalts north and south of Iceland: Earth Planet. Sci. Lett., v. 78, p. 1-17.

Richter, D. H.; Eaton, J. P.; Murata, K. J.; Ault, W. U.; and Krivoy, H. L., 1970, Chronological narrative of the 1959-60 eruption of $\mathrm{Ki}$ lauea Volcano, Hawaii: U.S. Geol. Survey Prof. Paper 537-E, 73 p.

Roedder, E., 1965, Liquid $\mathrm{CO}_{2}$ inclusions in olivine-bearing nodules and phenocrysts from basalts: Am. Mineral., v. 50, p. 1746-1782.

Roedder, P. L., 1974, Activity of iron and olivine solubility in basaltic liquids: Earth Planet. Sci. Lett., v. 23, p. 397-410.

Ryan, M. P.; Koyanagi, R. Y.; and Fiske, R. S., 1981, Modeling the three-dimensional structure of macroscopic magma transport systems: applications to Kilauea Volcano, Hawaii: Jour. Geophys. Res., v. 86, p. 7111-7129.

- 1988, The mechanics and three-dimensional internal structure of active magma sys- tems: Kilauea volcano, Hawaii: Jour. Geophys. Res., v. 93, p. 4213-4248.

SaKaI, H.; Des Marais, D. J.; Ueda, A.; and Moore, J. G., 1984, Concentrations and isotopic ratios of carbon, nitrogen, and sulfur in oceanfloor basalts: Geochim. Cosmochim. Acta, v. 48, p. 2433-2441.

Silver, L., and Stolper, E., 1989, Water in albitic glasses: Jour. Petrology, v. 30, p. 667-709.

Stolper, E., and Holloway, J. R., 1988, Experimental determination of the solubility of carbon dioxide in molten basalt at low pressure: Earth Planet. Sci. Lett., v. 87, p. 397-408.

Swanson, D. A., and FABBI, B. P., 1973, Loss of volatiles during fountaining and flowage of basaltic lava at Kilauea Volcano, Hawaii: Jour. Res. U.S. Geol. Survey, v. 1, p. 649-658.

Thompson, R. N., and Tilley, C. E., 1969, Melting and crystallization relations of Kilauean basalts of Hawaii. The lavas of the 1959-60 Kilauea eruption: Earth Planet. Sci. Lett., v. 5, p. 469-477.

Vergniolle, S., and Jaupart, C., 1990, Dynamics of degassing at Kilauea Volcano, Hawaii: Jour. Geophys. Res., v. 95, p. 2793-2809.

Wilde, P.; Chase, T. E.; Normark, W. R.; Thomas, J. A.; and Young, J. D., 1980, Oceanographic data off the southern Hawaiian Islands: Univ. of California, Lawrence Berkeley Laboratory Pub. 359, 1 p.

Wolfe, E. W.; Garcia, M. O.; Jackson, D. B.; Koyanagi, R. Y.; Neal, C. A.; and Okamura, A. T., 1987, The Puu Oo eruption of Kilauea Volcano, episodes 1-20, January 3, 1983, to June 8, 1984: U.S. Geol. Survey Prof. Paper 1350, p. 471-508.

Wright, T. L., 1971, Chemistry of Kilauea and Mauna Loa lava in space and time: U.S. Geol. Survey Prof, Paper 735, 40 p.

- , and FISKE, R. S., 1971, Origin of the differentiated and hybrid lavas of Kilauea Volcano, Hawaii: Jour. Petrol., v. 12, p. 1-65. 